Amasya Illahiyat Dergisi - Amasya Theology Journal

ISSN 2667-7326 | e-ISSN 2667-6710

Haziran / June 2019, 12: 153-194

\title{
Amasyalı Abdurrahman Kâmil (Yetkin) Efendi'nin Şairliği ve Türkçe Şiirleri
}

\section{The Poetry Skill and the Turkish Poems of Abdurrahman Kâmil (Yetkin) Efendi From Amasya}

\author{
Avni Erdemir \\ Dr. Öğr. Üyesi, Amasya Üniversitesi, Eğitim Fakültesi, Eski Türk Edebiyatı \\ Anabilim Dalı \\ Assistant Professor, Amasya University, Faculty of Education, Old Turkish \\ Literature Department \\ Amasya, Turkey \\ avni.erdemir@gmail.com \\ orcid.org/0000-0002-5659-5459
}

\section{Makale Bilgisi / Article Information}

Makale Türü / Article Types: Araştırma Makalesi / Research Article

Geliş Tarihi / Received: 24 Aralık / December 2018

Kabul Tarihi / Accepted: 18 Şubat / February 2019

Yayın Tarihi / Published: 20 Haziran / June 2019

Yayın Sezonu / Pub Date Season: Haziran / June

Sayı / Issue: 12 Sayfa / Pages: 153-194

Atıf / Cite as: Erdemir, Avni. “Amasyalı Abdurrahman Kâmil (Yetkin) Efendi'nin Şairliği ve Türkçe Şiirleri [The Poetry Skill and the Turkish Poems of Abdurrahman Kâmil (Yetkin) Efendi From Amasya]". Amasya Ilahiyat DergisiAmasya Theology Journal 12 (June 2019): 153-194.

https://doi.org/10.18498/amailad.579964.

İntihal / Plagiarism: Bu makale, en az iki hakem tarafından incelendi ve intihal içermediği teyit edildi. / This article has been reviewed by at least two referees and scanned via a plagiarism software.

Copyright ( Published by Amasya Üniversitesi, İlahiyat Fakültesi / Amasya University, Faculty of Theology, Amasya, 05100 Turkey. All rights reserved. https://dergipark.org.tr/amailad 
154 । A. ERDEMIR / Amasyalı Abdurrahman Kâmil (Yetkin) Efendi'nin Şairliği ve Türkçe Şiirleri

The Poetry Skill and the Turkish Poems of Abdurrahman Kâmil (Yetkin) Efendi From Amasya

\section{Abstract}

Abdurrahman Kâmil Efendi was born in Amasya in 1850 and died in the same city in 1941. His grandfather is Mustafa Mecdî Efendi and his father is Ahmet Rifat Efendi. After the invasion of Crimea by the Russians, his family moved to Mecitözü, a town of Amasya and they settled there. The family was known as Mecdîzâde related to the name of Mustafa Mecdî Efendi.

Abdurrahman Kâmil Efendi got a good religious education from the early ages of his childhood and he had adequate Arabic and Persian language skills to write poems. He had been a mufti and religious department sheik at Amasya Sultan Bâyezıd Mosque. He overtook a great responsibility during the national struggle of the Turkish People and played a key role during that period. He invited the local people to support the movement of independence.

Up to today, there have been a lot of researches carried on his books which are about his role in the national struggle period. However, there has no research done about his poems and poetry skills. Furthermore, he is, also, a poet and wrote some poems in Arabic, Persian and Turkish languages with the nickname Kâmil. In this article, his Turkish poems that he wrote with the nickname Kâmil were determined and his poetry skill was discussed.

As a result of this research we were determined 14 Turkish poems of him which includes 4 masnavi, 2 odes (kasida), a müsemmen and 6 ghazals. Kâmil Efendi has adopted the elements of comparison and the groups of words from the tradition of divan. The main theme of his poems on religion and mysticism is divine love.

In this article, the poems of Abdurrahman Kâmil Efendi with the nickname Kâmil were identified and presented the transcriptions of them; and gave information about him based on his poems

\section{Summary}

Abdurrahman Kâmil Efendi was born in Amasya in 1850 and died in the same city in 1941 His family moved from Crimea in 1783 when the Crimea was invaded by tre Russian army. They first settled in Mecitözü which was a town of Amasya in those years. They were called as Mecdîzâdeler. His father was Ahmet Rif'at Efendi and his grandfather, Mustafa Mecdî Efendi, was a scholar and a sheik of Nakşibendiyye.

Kâmil Efendi received a perfect thelogical education from the best scholars of his period and learned Persian and Arabic languages as much as to write poems in 
those mentioned languages. When he completed his education, he became a müderris (academician in madrasah) in Amasya, a preacher at Sultan Bayezid Mosque and he taught interpretation of Quran in different mosques. Abdurrahman Kâmil Efendi, who fulfilled the longest duty as a mufti in Amasya, was appointed as a mufti to Amasya at the age of 50 in May 1900, after the death of Amasya mufti Mehmed Efendi. He was retired in 1915 because of the age limitation. He taught some subjects between the years 1916-1920 at Dârülhilâfe Madrasah. After the death of Mufti Mehmed Tevfik Efendi in 1921, he was once again appointed as a mufti to Amasya by the order of Gazi Mustafa Kemal in 1922 and he carried on this duty up to 1941 which was the year he died.

He took a mission in the National struggle of Anatolia against enemies between the years 1919-1922. Gazi Mustafa Kemal Pasha who was seeking the support of the Anatolian people in those years visited Amasya as the first city to start the National struggle and the Amasya mufti Hacı Tevfik Efendi and Abdurrahman Kâmil Efendi welcomed and greeted him at the entrance of the city. Abdurrahman Kâmil Efendi who was the preacher of Sultan Bayezıd Mosque at that period addressed to the people on Friday, 13th June 1919 about the importance of the National Struggle to depict his support to Mustafa Kemal Pasha. Müdafaa-i Hukuk Cemiyeti was established on 14th June, 1919 with 17 members for the first time in Amasya and the first member of this community was Müftü Tevfik Efendi (d.1921) and the second one was Abdurrahman Kâmil Efendi.

Kâmil Efendi was married to Emine Hanım, the daughter of scholar Anaç Hoca in 1883 and he had three sons with the names Mehmed Sabri Yetkin, Ahmed Emri Yetkin and Mustafa Niyazi Yetkin and a daughter, Fatma Zehra. His sons also became the famous scholars of Amasya like himself.

There have been many studies done about the life, personality, books, poems and the role in National Struggle of Abdurrahman Kâmil Efendi who wrote many books on theological content. In these studies, it was mentioned that he was a poet with "Divançe". However, there has been no study about his poesy and his poems up to now. In this study, it is aimed to explain the poesy and the characterisitcs of his poems through giving the translated written texts in "Divançe" recorded under the name of Abdurrahman Kâmil Efendi with the number Yz. A 8993 in the handwritten book section of Ankara National Library.

This book in which we based on to determine the poems of Abdurrahman Kâmil Efendi was written as a mixture of verse-prose. The mystical ideas expressed in the prose sections were supported by poems written in Turkish, Arabic and 
156 | A. ERDEMIR / Amasyalı Abdurrahman Kâmil (Yetkin) Efendi'nin Şairliği ve Türkçe Şiirleri Persian languages and they were put into the appropriate places related to the topic.

He used nickname Kâmil in his poems. He wrote 14 Turkish poems in this book. In all these poems, verse styles, prosody forms and simile elements belonging to classical divan poem tradition are used successfully. In this aspect, it is possible to evaluate Abdurrahman Kâmil Efandi as one of the follower and a good example of a classical divan poem tradition in twentieth century.

This poem was written in the form of verse and consists of 4 masnavi, 2 odes (kasida), 1 muhammes (a section with five lines), 1 müsemmen (a section with six lines) and 6 ghazal(lyrics). These poems were techniquelly written excellently and they reflect all the characteristics of the verse styles.

He used 7 different prosody forms in his poems. However, he used double prosody form in his two poems which is accepted as an exception in classical poem tradition.

The poet was successful at using prosody verse. There have sometimes seen reduction of the pronounciation of the syllable (zihaf) in some of his poems. The words and syllables which must be pronounced with two syllables in which one of them is open and the other one is closed as in $b \hat{\imath} h, h \hat{\imath} c ̧, y \hat{a} r$ and tîz are pronounced as one closed syllable.

The words which should be pronounced as two syllables (med) are pronounced without two syllables (med), some consonants of Arabic language are pronounced related to the rules of Turkish pronounciation are the characteristics which the poet prefered in his poems. Most of these prosody faults in the poems of Abdurrahman Kāmil Efendi are the reflection of the characteristics of Turkish prosody changed in time to his poems.

The main theme of Abdurrahman Kâmil's poems is the love of God. He used the words to describe love in his poems with the meaning of mysticism where as the other poets of divan literature used these words to describe their love to their lovers. Lirism is dominant in his poems.

The book starts with a mesnevi with 19 couplets. The first poem of the book was written in the form of classical poem tradition and the poem starts with besmele, praise to God and pray to the Prophet. These subjects are stressed throughout the poem.

The themes of his other poems are about the pain of separation and convergency to the lover. His fourth book is a Mesnevi with 55 couplets. He wrote that Mesnevi for his great admiration to Seyh Şadi buried in Şeyhsadi village in Amasya.

Among the poems of Abdurrahman Kâmil Efendi, there is an eulogy written in "elifname" style. In this "elifname", Kâmil Efendi wrote one line for each letter of 
Arabic language consisted of 29 letters starting from the alphabet elif to last letter $y$. The letters in the poem are included into a rhythm.

His son Ahmet Emrî Yetkin claimed that his father had destroyed some of his poems and some of them were lost because of unknown reasons. Why he ruined his poems by himself was not known clearly. The destruction of the poems of Abdurrahman Kâmil who was one of the good example of 16th century classical divan poem tradition in 20th century was a great lost for Turkish literature. If his lost poems are found and then published, it will yield to make a healthier evaluation about his poesy and poems.

Keywords: Old Turkish Literature, Abdurrahman Kâmil Efendi, Mecdîzâde, Amasya, Poet.

\section{Amasyalı Abdurrahman Kâmil (Yetkin) Efendi'nin Şairliği ve Türkçe Şiirleri}

$\ddot{O} z$

Abdurrahman Kâmil Efendi, 1850 yılında Amasya'da doğmuş ve 1941'de Amasya'da vefat etmiştir. Dedesi Mustafa Mecdî Efendi, babası Ahmed Rif'at Efendi'dir. Kırım'ın Ruslar tarafından ilhakı üzerine ailesi, o dönemde Amasya'ya bağlı bir kaza olan Mecitözü'ye yerleşmiştir. Dedesi Mustafa Mecdî Efendi'ye nisbetle aile Mecdîzâdeler olarak bilinmektedir.

Abdurrahman Kâmil Efendi, çocukluğundan itibaren iyi bir dinî eğitim almış; eser yazacak kadar Arapça ve Farsçaya vâkıf olmuştur. Amasya Sultan Bayezid Camii kürsü şeyhliği ve uzun yıllar Amasya müftülüğü yapmıştır. Millî mücadelede önemli görev ve sorumluluklar üstlenmiş; bir din adamı olarak halkı milli mücadeleye destek vermeye çağırmıştır.

Dinî nitelikte çok sayıda eser veren Abdurrahman Kâmil Efendi'nin bu eserleri ve milli mücadeledeki rolü ile ilgili günümüze kadar çok sayıda çalışma yapılmış; ancak şiirleri ve şairliği üzerinde hiç durulmamıştır. Oysa Abdurrahman Kâmil Efendi, Kâmil mahlasıyla Arapça, Farsça ve Türkçe şiirler yazmıştır.

İnceleme sonunda, Abdurrahman Kâmil Efendi'nin 4 mesnevi, 2 kaside, 1 muhammes, 1 müsemmen ve 6 gazel olmak üzere, toplam 14 Türkçe şiiri tespit edilmiştir. Kâmil Efendi, şiirlerinde divan şiiri geleneğinin mazmun ve benzetme unsurlarını kullanmıştır. Dinî ve tasavvufî mahiyette olan şiirlerinin konusu ilâhî aşktır.

Bu makalede Abdurrahman Kâmil Efendi'nin Kâmil mahlasıyla yazdığı Türkçe şiirlerinin tespiti yapılmış, bunların çeviriyazılı metinleri ortaya konmuş ve şiirlerinden hareketle şairliği hakkında bilgiler verilmiştir. 
158 | A. ERDEMIR / Amasyalı Abdurrahman Kâmil (Yetkin) Efendi'nin Şairliği ve Türkçe Şiirleri Anahtar Kelimeler: Eski Türk Edebiyatı, Abdurrahman Kâmil Efendi, Mecdîzâde, Amasya, Şair.

\section{Hayat1}

Abdurrahman Kâmil Efendi'nin soyu, 1783 yılında Kırım'ın Ruslar tarafından ilhakı üzerine, o dönemde Amasya'ya bağlı Mecitözü kazasına yerleşen Mecdîzâde ailesine dayanmaktadır. Babası, Ahmet Rif'at Efendi; dedesi, dönemin âlim ve Nakşibendiyye şeyhlerinden Mustafa Mecdî Efendi’ dir. Mustafa Mecdî Efendi'nin babası da Hasan Efendi'dir. Hasan Efendi, Amasya'ya bağlı Ziyaret beldesinde medfun olan Abdülbâkî Hicâbî ile Kırım'dan Amasya'ya hicret etmiş ve Mecitözü’ye yerleşmiştir. Hasan Efendi, burada ilme dair bir teveccüh görmeyince Mecitözü' de dünyaya gelen oğlu Mustafa Mecdî ile beraber Amasya'ya gelerek Gümüşlü mahallesine yerleşmiştir.

Dedesi Mustafa Mecdî’ye nisbetle kendisine Mecdîzâde diyen Abdurrahman Kâmil Efendi, 1266/1850 yılı cemâziye'l-âhir ayının on beşinde (28 Nisan 1850) Amasya'da doğmuştur. 1271/1854-55 y1lında sıbyan mektebine girmiş; 1278/1861-62'de burada Madenüscü ismiyle tanınan Sıbyan muallimi Mustafa Efendi gözetiminde Kur'ân'1 ezberleyerek hâfız olmuştur. İki sene de kırâat ve tecvid dersleri alan Abdurrahman Kâmil, 1280/1863-64 y1lında Amasya mutasarrıfı Ziya Paşa'nın yaptırdığı Rüştiye mektebinde okumuş, 1285/186869'da ise Mehmet Paşa Medresesine gitmiştir. Burada beş y1l temel ilimler eğitimi almıştır. Aynı yıllarda ağabeyi Sadık Efendi’den (ö.1321/1903-4) kırâat, ferâiz ve ilm-i arûz dersleri almıştır. Yedi sene de devrin âlimlerinden fikıh, fıkıh usulü, hadis, hadis usulü, tefsir ve aklî ilimler eğitimi görmüș ve 1297/1879-80'de Mir Hasan Efendi' den icâzet alarak eğitim faaliyetine başlamıştır. ${ }^{1}$

Amasya Sultan Bayezid Camii'nde kürsü şeyhliği de yapan Abdurrahman Kâmil Efendi, müftü olmadan önce her sene Ramazan ayında halka yönelik tefsir dersleri; yine Gümüşlü Camii'nde sabah ve ikindi namazlarında tefsir dersleri vermiştir. Bu dersler halkın ilgisine mazhar olmuştur. ${ }^{2}$

1 Recep Orhan Özel, “Amasya'da Bir Âlim Yuvas1: Mecdîzâde Abdurrahman Kâmil Yetkin (Ö.1941) ve Oğulları Mehmet Sabri Yetkin (Ö.1963), Ahmet Emrî Yetkin (Ö.1974), Mustafa Niyazi Yetkin (Ö.1959)”, Amasya Üniversitesi Ilahiyat Fakültesi Dergisi 6/10 (Haziran 2018): 42-46.

2 Özel, “Amasya'da Bir Âlim Yuvası: Mecdîzâde Abdurrahman Kâmil Yetkin (Ö.1941) ve Oğulları Mehmet Sabri Yetkin (Ö.1963), Ahmet Emrî Yetkin (Ö.1974), Mustafa Niyazi Yetkin (Ö.1959)", 47. 
Abdurrahman Kâmil Efendi, Anadolu'nun kurtuluş mücadelesinde de önemli görevler üstlenmiştir. Gazi Mustafa Kemal Paşa, halk desteği arayışındaki ilk duraklarından biri olan Amasya'da, Amasya müftüsü Hacı Tevfik Efendi ve Abdurrahman Kâmil Efendi tarafından karşılanmıştır. O zaman Sultan Bayezid Camii vaizi olan Abdurrahman Kâmil Efendi, 13 Haziran 1919 günü yaptı̆̆ 1 Cuma vaazında halka milli mücadelenin önemini anlatmıştır. 14 Haziran 1919'da kurulan Amasya Müdafaa-i Hukuk Cemiyeti'nin 17 kişilik isim listesinin başında Müftü Tevfik Efendi (ö.1921) ikinci sırasında ise Abdurrahman Kâmil Efendi vardir. ${ }^{3}$

1300/1882-83 yılında Amasyalı âlim Anaç Hoca'nın kızı Emine Hanım'la evlenen ${ }^{4}$ Abdurrahman Kâmil Efendi, Arapça ve Farsça bilmekte olup Amasya müftüsü Mehmed Efendi'nin vefatı üzerine 1318/1900 y1lı Muharrem (May1s) ayında 50 yaşında iken meşîhat makamınca fetvâya mezun olmuş ve Amasya müftülüğüyle birlikte Sivas ve Karadeniz bölgesi vaizliği görevine getirilmiştir. Hicaz Demiryolu İâne Komisyonu'ndaki hizmetinden dolayı 1903'te nişan ve madalya ile taltif edilmiş; aynı yıl kendisine Mûsıle-i Süleymâniye-i Râbia'dan Bursa Fakihzâde Medresesi pâyesi, 1905’te İzmir Payesi verilmiştir. 1912 y1lında yanlışlıkla emekliye sevkedildiyse de yanlışlık düzeltilerek görevine dönmüş ve 1 Eylül 1331/1915 yılında yaş haddinden emekli edilmiştir. 1916-1920 yıllarında Dârülhilâfe Medresesi'nde ders vermiştir. Müftü Mehmed Tevfik Efendi'nin 1921'de vefatından sonra Gazi Mustafa Kemal'in emriyle Temmuz 1338/1922 yılında tekrar Amasya müftülüğüne tayin edilmiş ve vefat ettiği 18 Kanun-1 evvel 1941 y1lı perşembe gününe kadar bu görevi yürütmüştür. ${ }^{5}$ Cenaze namazı oğlu

3 Abdurrahman Kâmil Efendi'nin Millî Mücadele'deki görev ve fonksiyonları hakkında geniş bilgi için bk. Ali Sarıkoyuncu, "Millî Mücadelede Amasya Müftüleri (Hacı Tevfik ve Abdurrahman Kâmil Efendiler)", Diyanet IIlmi Dergi 31/2 (1995): 61-100; Songül Keçeci Kurt, "Son Dönem Osmanlı Ulemasının Önemli Şahsiyetlerinden Abdurrahman Kâmil Efendi (1850-1941)", Türkiyat Araştırmaları Dergisi-Journal of Turkish Researches Institute, 60 (Eylül-September 2017): 477494.

4 Özel, “Amasya'da Bir Âlim Yuvas: Mecdîzâde Abdurrahman Kâmil Yetkin (Ö.1941) ve Oğulları Mehmet Sabri Yetkin (Ö.1963), Ahmet Emrî Yetkin (Ö.1974), Mustafa Niyazi Yetkin (Ö.1959)", 46.

5 Kâmil Şahin, "Abdurrahman Kâmil Yetkin”, Türkiye Diyanet Vakfi İslam Ansiklopedisi (Ankara: TDV Yayınları, 2013), 43: 504-505; Mustafa Murat Batman, “Osmanlı'nın Son Döneminden Cumhuriyete Uzanan Bir Âlim: Amasyalı Abdurrahman Kâmil (Yetkin) Efendi”, Uluslarası Amasya Âlimleri Sempozyumu Bildiriler Kitabı 2, (21-23 Nisan 2017), ed. Şuayip Özdemir - Ayşegül Gün (Ankara: KIBATEK, 2017), 2: 510-511. 
160 । A. ERDEMIR / Amasyalı Abdurrahman Kâmil (Yetkin) Efendi'nin Şairliği ve Türkçe Şiirleri Mehmet Sabri Yetkin tarafından kıldırılmış ve Şamlar Mezarlığına defnedilmiştir. ${ }^{6}$

Kâmil Efendi'nin Mehmed Sabri Yetkin, Ahmed Emri Yetkin ve Mustafa Niyazi Yetkin olmak üzere üç oğlu ve Fatma Zehra isimli bir kızı vardır. Oğulları da kendisi gibi Amasya'nın son devrinde yetişmiş önemli âlimlerdendir. ${ }^{7}$

\section{Eserleri}

\section{Nakdü'l-Hâtır Fî Cilâi'n-Nâzır}

Eserin müellif hattı nüshası, Amasya Yazma Eserler Kütüphanesi’nde 1708/1 numarada kayıtlıdır. İlk dört sayfanın konusu ahlâk olup sonraki kısımlarda Hz. Muhammed'in mucizeleri ve Veysel Karânî'nin kıssası yer almaktadır. Eser, yazarın vefatından üç yıl önce 1938 yılında tamamlanmıştır. Amasya Yazma Eserler Kataloğu 1708/2 numarada Dürer-i Zebân ismiyle kayıtlı olan eser, müstakil bir eser olmayıp bazı değişikliklerle beraber birinci bölümün aynısıdır. Müellif, bu bölümde eserin adını Nakdü'l-hâtır fî cilâi'n-nâzır olarak güncellemiştir. Eser Türkçedir.

\section{Tebyînü'l-Muğlakât ve'l-Mühimmât min Elfâzi'l-Makâmât}

Amasya Yazma Eserler Kütüphanesi 1734 numarada kayıtlı olan eser, müellif hattı olup 28 varaktır. 1339/ 1920-21 yılında tamamlanmıştır. Eser, Ebû Muhammed el-Kâsım el-Harîrî’nin (öl. 516/1055) Makâme isimli elli küçük hikâyeden oluşan eseri hakkındadır. Abdurrahman Kâmil Efendi, manzum olan bu kitaptaki kelimelerin lugat anlamlarını vermiş ve metin içindeki anlamına dair açıklamalar yapmıştır. Milli Kütüphane 927 numarada Besâ'irü'l-kemâlât fî tercemeti'l makâmât ve yine aynı kütüphane 7592 numarada Dîbâce-i müfredât ismiyle kayıtlı eser, aynı eserdir. En kapsamlı nüsha, Milli Kütüphane 7592 numaralı nüsha olup eser 288 varaktır. $\mathrm{Bu}$ eser, Arapçada ileri düzeye gelmiş öğrenciler ve Dârü'l-hilâfe medresesinde ders okutan hocalara yardımcı olacağ1 düşünülerek yazılmıştır. ${ }^{8}$ Eserin dili Türkçedir.

6 Özel, “Amasya'da Bir Âlim Yuvas: Mecdîzâde Abdurrahman Kâmil Yetkin (Ö.1941) ve Oğulları Mehmet Sabri Yetkin (Ö.1963), Ahmet Emrî Yetkin (Ö.1974), Mustafa Niyazi Yetkin (Ö.1959)", 49.

7 Abdurrahman Kâmil Efendi'nin çocuklarının hayatı ve eserleri hakkında geniş bilgi için bk. Özel, "Amasya'da Bir Âlim Yuvas1: Mecdîzâde Abdurrahman Kâmil Yetkin (Ö.1941) ve Oğulları Mehmet Sabri Yetkin (Ö.1963), Ahmet Emrî Yetkin (Ö.1974), Mustafa Niyazi Yetkin (Ö.1959)", 54-69.

8 Özel, “Amasya'da Bir Âlim Yuvası: Mecdîzâde Abdurrahman Kâmil Yetkin (Ö.1941) ve Oğulları Mehmet Sabri Yetkin (Ö.1963), Ahmet Emrî Yetkin (Ö.1974), Mustafa Niyazi Yetkin (Ö.1959)", 51-52. 


\section{3. Şerh-i Bostân}

Sa'dî-i Şîrâzî’nin Farsça kaleme aldığı Bostan isimli eserinin yarım kalmış Arapça şerhi olan eser, Milli Kütüphane Yazmalar Koleksiyonu 5672 numarada kayıtlı olup 204 varaktır.

\section{Terâcim-i Ahvâl}

Eser, Milli Kütüphane'de 7952 numarada kayıtlıdır. Biyografik bir çalışma olan eserde, kaf harfiyle başlayan isimlerin biyografisi verilmektedir. Kâmil Şahin, özel kütüphanesinde Abdurrahman Kâmil'e ait müellif hatt1 160 sayfalık evliya, ulemâ ve şuarâdan alfabetik sıraya göre bazı zatların hayat hikâyelerini anlatan bir eserin bulunduğunu ifade etmektedir. ${ }^{9}$ Milli Kütüphane'deki bu eser, Kâmil Şahin'in sözünü ettiği biyografik eserin kaf harfiyle başlayan bölümü olabilir. Zira eserin Milli Kütüphane kaydındaki, notlar bölümünde 1994 y1lında Şahin Kitabevi'nden satın alındığına dair not vardır. Eserin dili Türkçedir.

\section{Mevâiz}

Milli Kütüphane 7956, 7970 ve 8579 numaralarda kayıtlı yazmalar, Abdurrahman Kâmil Efendi'nin değişik konulardaki vaazlarını ihtiva etmektedir.

\section{Mir'âtü'ş-Şü'ûni'l-Hakâ'ik}

Kâmil Şahin'in bildirdiğine göre ${ }^{10}$ bu eser, özel kitaplığındaki bir mecmuanın içinde olup (323-335) Ahmed Hüsameddin Dâğıstânî'nin istihrâc alanındaki eserinin Türkçe çevirisidir. Bu eserde 71 maddede gelecekte vuku bulacak olaylar ve devletlerin maruz kalacakları felaketler konu edilmektedir.

\section{Hâtırât-1 Abdurrahman Kâmil}

Kâmil Şâhin'in özel kitaplığında bulunan eser, 1903'te yazılmış olup 33 varaktır. ${ }^{11}$

\section{8. Şerhu Ziyâdeti'l-Mer'}

Kâmil Şâhin'in verdiği bilgiye göre ${ }^{12} 1904$ 'te yazılmış olan bu eser, özel kitaplığında bulunan Hâtırât-1 Abdurrahman Kâmil isimli eserin 29b-31b varakları arasındadır. Eser, Ebulfeth el-Büstî’nin (öl.401/1010) Kasîde-i Nûniyye isimli eserine yapılmış bir şerhtir.

\footnotetext{
Şahin, “Abdurrahman Kâmil Yetkin”, 43: 505.

Sahin, "Abdurrahman Kâmil Yetkin", 43: 505.

Şahin, "Abdurrahman Kâmil Yetkin”, 43: 505.

Şahin, "Abdurrahman Kâmil Yetkin”, 43: 505.
} 
162 | A. ERDEMIR / Amasyalı Abdurrahman Kâmil (Yetkin) Efendi'nin Şairliği ve Türkçe Şiirleri

\section{Yasin Suresi Tefsiri}

Eser, Milli Kütüphane 2782 numarada kayttlı olup 160 sayfadan oluşmaktadır. Çoğunlukla çeşitli tefsirlerden alınan notlardan oluşan eser, eksiktir. Katalog kaydında eserin Lübâbü't-te'vîl adıyla kayıtlı olması ve Abdurrahman Kâmil Efendi’nin müstensih olarak gösterilmesi yanlıştır.

\section{Diğer Eserleri}

Kâmil Şâhin, ${ }^{13}$ özel kitaplığında bu eserlerin dışında Abdurrahman Kâmil'in Amasya Bayezid Camii'ndeki vaazlarından oluşan tefsir dersleri notları ve Hz. Peygamber'in Risâleti adlı bir eserinin daha olduğunu bildirmektedir.

\section{Abdurrahman Kâmil Efendi'nin Divançesi, Türkçe Şiirleri ve Şairliği}

Abdurrahman Kâmil Efendi'nin ilmî şahsiyeti ve millî mücadeledeki rolü ile ilgili günümüze kadar önemli çalışmalar yapılmış; bu çalışmalarda aynı zamanda divançe sahibi bir şair olduğu ifade edilmiş; ancak şiirleri hakkında herhangi bir çalışma yapılmamıştır. Bu makale ile Milli Kütüphane Yazmalar Koleksiyonu Yz. A 8993 numarada Abdurrahman Kâmil Efendi adıyla kayitl, Divançe isimli yazma eserdeki Türkçe şiirlerin çeviriyazılı metinleri verilmiş ve bu şiirlerden hareketle onun şairliği ve şiirinin özellikleri ortaya konmaya çalışılmıştır.

Abdurrahman Kâmil Efendi hakkında yapılan çalışmalarda onun şairliği ile ilgili verilen bilgiler, "Dinî ilimlerin yanısıra, șiirle de ilgilenen Abdurrahman Kâmil", 14 "şiire ilgi duymuş duygu ve düsünncelerini manzum tarzda ifade etmiştir. Oğlu Ahmet Emrî Yetkin, şiirlerinin bir kısmını kendisinin imha ettiği, bir kısmının ise kaybolduğunu söylemektedir. " $" 15$ şeklinde ifade edilen cümlelerden ibarettir.

Abdurrahman Kâmil Efendi'nin aynı zamanda şair olduğunu ifade eden yukarı verilen bigilerin dışında, onun divan sahibi olduğuna dair bilgiler de kaynaklarda yer almaktadır. Bu bilgilerin çoğu Kâmil Şâhin'in İslâm Ansiklopedisi'nde yazdığı "Abdurrahman Kâmil Yetkin" maddesinde verilen bilgilerin tekrarı mahiyetindedir. Kâmil Şâhin'in verdiği bilgiye göre Abdurrahman Kâmil Efendi, "Arapça ve Farsça şiirlerinin de yer aldığı divanını

13 Şahin, “Abdurrahman Kâmil Yetkin”, 43: 505.

14 Sarıkoyuncu, "Millî Mücadelede Amasya Müftüleri (Hacı Tevfik ve Abdurrahman Kâmil Efendiler)", 82.

15 Özel, “Amasya'da Bir Âlim Yuvası: Mecdîzâde Abdurrahman Kâmil Yetkin (Ö.1941) ve Oğulları Mehmet Sabri Yetkin (Ö.1963), Ahmet Emrî Yetkin (Ö.1974), Mustafa Niyazi Yetkin (Ö.1959)", 50. 
1884 'te tamamlamıs, eserin sonunda kendi biyografisine yer vermiştir. "'l6 Songül Keçeci Kurt, makalesinde Kâmil Şahin'e yaptığı atıfta şair, "Arapça ve Farsça şiirlerinin de olduğu divanını 1884'te tamamlamıştır. ${ }^{, 17}$ demektedir.

Mustafa Murat Batman, Abdurrahman Kâmil Efendi'nin divanı ve şairliği ile ilgili şu bilgileri vermektedir: "Dîvân-1 Kâmil, Abdurrahman Efendi'nin Türkçe, Arapça ve Farsça şiirlerinin de yer aldı̆̆ı kendi divanıdır. Buradan hareketle hoca efendinin Farsça'ya da hâkim olduğunu anliyoruz. Kâmil Efendi, esere Gümüşlü Camii’ndeki vaizlik görevi esnasında 1884 yılında başlamış ve aynı yıl bitirmiştir. ${ }^{18}$ Ayrıca eserde çağdaşı olan ilmiye sınıfina mensup zatlara yazdı̆̆ siirleri de bulunmaktadır. Eserin sonunda da kendi biyografisi de diyebileceğimiz özel notlan bulunmaktadır. Müellif hattı olan eser Kâmil Şâhin özel kitapllğındadır. ${ }^{\prime 19}$

Recep Orhan Özel ise, mürettep bir divan olmamas1 sebebiyle, esere divançe demiş ve eserle ilgili olarak şu bilgileri vermiştir: "Milli Kütüphane 8993 numarada kayitlı olup 98 sayfadan oluşan eser, Abdurrahman Kâmil Efendi'nin Hicri 1302 (m. 1884) yılinda Gümüşlü Camii’nde Beyzavî Tefsiri'nden yaptı̆ğ dersler sırasındaki duygularını ifade etmektedir. Eserde çeşitli ahlâkî konulara dair Türkçe ve Arapça beyitlere yer verilmiş ve mecâzî aşktan ilâhî aşka intikal süreci manzum-mensur şekilde işlenmiştir. ${ }^{20}$

Batman, divanın müellif hattı nüshasının Kâmil Şahin'in özel kütüphanesinde olduğunu söylemektedir. Ne var ki Kâmil Şahin, 2013'te Diyanet Vakfi İslâm Ansiklopedisi'nde yayımlanan "Abdurrahman Kâmil Yetkin"

16 Şahin, "Abdurrahman Kâmil Yetkin”, 43: 505.

17 Kurt, "Son Dönem Osmanlı Ulemasının Önemli Şahsiyetlerinden Abdurrahman Kâmil Efendi (1850-1941)", 485.

18 Eserin 1884 yılında yazılmaya başlayıp aynı yılın sonunda bittiğine dair Kâmil Şâhin'e atıfla verilen bilgilerin yanlış olduğunu düşünmekteyiz. Eserin girişinde verilen "üç yüz iki ramazan ayı" (s.2) Haziran 1885 'e karșllık gelmektedir. Eserin bitiş tarihi ise Şeyh Şâdî Türbesi'nin yapımında görevlendirilen Aburrahman Kâmil Efendi'nin bu türbeyi ziyaretten iki gün sonra yazdığ bilgiye dayandırılmaktadır. Abdurrahman Kâmil Efendi burada "Üç yüz sekiz ağustosu sekizinci günü” Şeyh Şâdî Türbesi'ni ziyaret ettiğini, iki gün sonra da şiirini yazdığını ifade etmektedir. Eğer eserin bitiş tarihi olarak son şiirin yazıldığı bu tarihi esas alırsak; eserin bitiş tarihi, 10 Ağustos 1890 'dır.

19 "Batman, Osmanlı'nın Son Döneminden Cumhuriyete Uzanan Bir Âlim: Amasyalı Abdurrahman Kâmil (Yetkin) Efendi”, 512.

20 Özel, “Amasya'da Bir Âlim Yuvası: Mecdîzâde Abdurrahman Kâmil Yetkin (Ö. 1941) ve Oğulları Mehmet Sabri Yetkin (Ö. 1963), Ahmet Emrî Yetkin (Ö. 1974), Mustafa Niyazi Yetkin (Ö. 1959)", 52. 
164 । A. ERDEMIR / Amasyalı Abdurrahman Kâmil (Yetkin) Efendi'nin Şairliği ve Türkçe Şiirleri maddesinde, divanın özel kütüphanesinde olduğuna dair bir bilgi vermemektedir. Üzerinde çalıştığımız eser, Milli Kütüphane Yazmalar Koleksiyonu Yz. A 8993 numarada Mecdîzâde Abdurrahman Kâmil adına Divançe ismiyle kayıtlıdır. Bu eserin sağ dış kapağında "satın alma: Şahin Kitabevi, 2002; sol dış kapağında ise fiyat1: 400.0000.000 TL" notu, 98. sayfasında ise Kâmil Şahin'in latin harfleriyle, kurşun kalemle yazdığı "Amasya Müftüsü Mecdîzâde Abdurrahman Kâmil Yetkin'in (ö.1941) divanı hakkında Kâmil Şahin'i görmeden kimse çalışma yapmasın, çünkü kâğıtlar halinde şiirleri de vardır. 09. 07. 2002" tarih ve imzalı notu bulunmaktadır. ${ }^{21} \mathrm{Bu}$ bilgiler bize Kâmil Şahin'in elindeki nüshayı Milli Kütüphane'ye 09 Temmuz 2002'de sattığını göstermektedir.

\section{Eserin Nüsha Tavsifi}

Müellif hattı olan eser, Milli Kütüphane Yazmalar Koleksiyonu Yz. A 8993 numarada, Divançe ismiyle kayıtlı olup 98 sayfadır. Manzum-mensur karışık olan eser şu beyitle başlar:

Matla'-1 envâr-1 Kur'ân-1 Kerîm

Oldı Bismillâhirrahmânirrahîm

Dîvânçe'nin son beyti şudur:

Hülâsâ Kâmilin meyli vefâya

Marîzdir tâkatı yokdur cefâya

98 sayfadan oluşan nüsha, ciltsiz olarak 225x163; 180x1217 mm ölçülerindeki kâğıda, 19 satır halinde, ta'lik hatla yazılmıştır.

Yazma nüshada bazı beyitler ve duraklar kırmızıdır. Şirazesi bozuk olup onarım görmüştür. Eser, 80. sayfaya kadar sayfa sonlarındaki ayağa uygun giderken 80. sayfadan 81. sayfaya geçişte metin, “Görmemek yeğdür görüp dîvâne olmakdan seni" mütekerrir misra1yla devam etmesi gerekirken; aynı eserin başka bir nüshasından koparılmış; sebeb-i te’lif bölümünün yer aldığı ilk sayfası yeniden başlamaktadır.

Yazma nüshanın 81 ve 82. sayfaları; ikinci sayfanın yedinci satırından dördüncü sayfanın altıncı satırına kadar olan bölümün aynen tekrarıdır. Nüshanın 83. ve 84. sayfaları, 17. sayfanın dördüncü satırından 18. sayfanın 16. satırına kadar olan bölümün, 85 ve 86 . sayfaları, 15. sayfanın üçüncü satırının son iki kelimesinden itibaren 17. sayfanın dördüncü satırının ilk kelimesine kadar olan bölümün aynısıdır.

21 Abdurrahman Kâmil Efendi'nin üzerinde çalıştığımız yazma nüsha dışında kaâğıtlar hâlinde şiirlerinin bulunduğunu ifade eden Kâmil Şahin Beyle görüşülmüş, ancak sözü edilen bu şiirlere ulaşılamamıştır. 
Yazma nüshanın 86. sayfasından sonra gelen sayfaya numara verilmemiştir. Çalışmamızda nüshada verilen numaralar esas alınmış ve sayfa numaralarında değişikliğe gidilmemiştir. $\mathrm{Bu}$ sebeple üzerinde numara bulunmayan bu sayfaya $86 \mathrm{~b}$ numarası verilmiştir.

Abdurrahman Kâmil Efendi, eserde tasavvufî görüşlerini mensur bir şekilde aktarırken duygularunı ifade için yer yer şiirlerden de yararlanmış; şiirler, yazma nüshada mensur kısımlar içinde konuya uygun olarak serpiştirilmiştir. $\mathrm{Bu}$ makalede şiirler yazma nüshadaki sıraya göre değil, nazım şekillerine göre mesneviler, kasideler, musammatlar, gazeller şeklinde tasnif edilerek verilmiştir.

Eserin istinsah kaydı bulunmamaktadır. Ön sözünde 302 Ramazan ayında (1302/1885 Haziran) yazılmaya başlandığ ${ }_{12}^{22}$ ifade edilmektedir. Abdurrahman Kâmil Efendi, yazma eserin son şiirinin başında ${ }^{23}$ Şeyh Şâdî Türbesi'nin ${ }^{24}$ yeniden inşası için görevlendirilmesi üzerine, 8 Ağustos $1308 / 1892^{25}$ (20 Ağustos 1892) tarihinde Şeyh Şâdî Köyü'ne gittiğini ve iki gün sonra ona olan muhabbetini ifade için 55 beyitlik mesneviyi yazdığını söylemektedir. Bu bilgilere göre eser, Haziran/Temmuz 1885 'de yazılmaya başlanmış ve 20 Ağustos 1892 tarihinde tamamlanmıştır.

\section{Eserin Adı ve Yazılış Sebebi}

Eser, manzum-mensur karışık yazılmış olup mensur kısımlar, manzum kısımlardan daha uzundur. Bu manada esere klâsik bir divan/divançe demek mümkün değildir.

Yazma nüshanın metin kısmında, eser adına dair açık hiçbir bilgi bulunmamaktadır. Nüshanın dış kapağında ise Dîvân-1 Kâmil Mecdîzâde ibaresi vardır. Bu ibarenin yazı cinsi ve yazı şekli, yazma nüshadaki metnin yazısına benzememektedir. Muhtemelen sonradan eklenmiştir. Bu ibareyi ekleyen kişi,

22 Mecdî-zâde Abdurrahman Kâmil, Divançe, Milli Kütüphane Yazmalar Koleksiyonu Yz. A 8993, 2.

23 Mecdî-zâde Abdurrahman Kâmil, Divançe, 93.

24 Şeyh Şâdî, Amasya evliyasındandır. Hangi devirde yaşadığı bilinmiyor. Hüseyin Hüsameddin'in verdiği bilgiye göre, Türbesi Amasya'nın Şeyhsadi köyünün eteklerinde olup 1409 yılında Karakeçilioğullarından Muslihiddin Musa Bey tarafından yaptırılmıştır (Hüseyin Hüsameddin, Amasya Tarihi, 1. Baskı (İstanbul: Hikmet Matbaası, 1327), 1: 342. Bu köyün günümüzdeki adı Şeyhsadi'dir. Köy, adını Şeyh Şādî'den almıştır. Tokat istikametinde Amasya merkeze $50 \mathrm{~km}$ uzaklıktadır.

25 Eserde verilen 8 Ağustos ayı, hicrî değil rûmîdir. Dolayısıyla tarih mîlâdiye çevrilirken rûmîden çevirilmiştir. 
166 | A. ERDEMIR / Amasyalı Abdurrahman Kâmil (Yetkin) Efendi'nin Şairliği ve Türkçe Şiirleri eser adına dair bir bilgi bulamayınca, Kâmil mahlasıyla yazılmış şiirleri dikkate alarak kapağa bu ismi yazmış olmalıdır.

Abdurrahman Kâmil Efendi, eserin yazılış sebebini, sebeb-i te'lif bölümünde;

"Ba'de-zâ sebeb-i tahrîr-i nemîka-i fîrâk ve mûcib-i tastîr-i vesîka-i iştiyâk budur ki hicret-i nebeviyyenin üç yüz iki sâl-i ferruh-fâli ramazân-1 mağfiretnişânında (Haziran/Temmuz 1885) ilhâh-1 enâdim iktirâh-1 'avâm ile

Dil ü cânı riyâdan pâk u sâde

Muhabbet geştesi bu Mecdîzâde"26 şeklinde açıklamaktadır.

Yukarıdaki sebeb-i tahrîr-i nemîka-i firâkve mûcib-i tastîr-i vesîka-i iştiyâk cümleleri, ayrılık mektubunu yazma sebebi, yüksek arzu (aşk) belgesini te'lif etme sebebi anlamina gelmektedir. Bu bilgiden hareketle eserin isminin ayrilik mektubu, aşk mektubu anlamlarına gelen Nemîka-i Firâk ve Vesîka-i İștiyâk olması ihtimal dahilindedir. Nitekim eserin giriş bölümünde verilen yukarıdaki beyitte Abdurrahman Kâmil Efendi kendisini, muhabbet geştesiolarak tanımliyor. Muhabbet geştesi; muhabbet gezgini, muhabbet fedâisi; mecazen âşık anlamına gelmektedir.

Eser, kendisini Hak âşığg olarak ifade eden Abdurrahman Kâmil Efendi’nin ilâhî aşk yolundaki seyr ü seferini anlatmaktadır. Kâmil Efendi, eserinin yazılış sebebini dostlarının ısrarına, halkın arzusuna bağlamaktadır. Eserde bu husus, ilhâh-1 enâdim ve iktirâh-1 'avâm, yani dostların 1srârı, halkın arzusu şeklinde ifade edilmektedir.

Abdurrahman Kâmil Efendi, eserin giriş bölümünün devamında, Amasya Gümüşlüzâde Ahmed Paşa Camii'nde tefsir dersleri verdiğini, Beydâvi Hazretlerinin Envâr-1 Tenzîl ve Esrâr-1 Te'vîl isimli kitabından Vâkı'a suresinin tefsirini okuduğu sırada oluşan duygularla hazırda bulunanlara ilâhî aşk şarabını sunduğunu, onların gönüllerini aydınlattığını söylemekte ve bu konudaki görüşlerine ağdalı bir dille manzum-mensur karışık bir şekilde devam etmektedir.

\section{Yazma Nüshada Abdurrahman Kâmil'e Ait Türkçe Şiirlerin Tespiti}

Manzum-mensur karışık olan eserin mensur kısımları, tam bir secîli nesir örneğidir. Manzum kısımlar ise Arapça, Farsça ve Türkçe şiirlerden oluşmaktadır. Abdurrahman Kâmil Efendi, mensur kısımlarda tasavvufi görüşlerini ortaya koymuş; bu husustaki görüşlerini ve duygularını konuya uygun şiirlerle

26 Mecdîzâde Abdurrahman Kâmil, Divançe, 2. 

şiirlerdir.

27 Eserde Nâbî'den (s.37-38), Fuzûlî'den (s.73), Bursalı Cinânî'den (s.79-80) şiirler bulunmaktadır. Abdurrahman Kâmil Efendi eserinde, alıntı yaptığı şiirlerin Nâbî ve Fuzûlî’ye ait olduğunu ifade etmiş; fakat Bursalı Cinânî'ye herhangi bir atıf yapmamıştır. Şair, tasavvufi görüşlerini ve duygularını ifade için yazdığı bir şiir hakkında, aşağıdaki muhammes-i âtîyi tilâvet ettim, demektedir. $\mathrm{Bu}$ muhammesin bulunduğu 80. sayfadan sonra, eser metninin ilk sayfasının yapıştırıldığı ve bu muhammesin noksan olduğu tespit edilmiştir. Muhammesin mahlas beyitinin yer aldığı son bend yazma nüshada yoktur. Bundan şüphelenerek yaptığımız araştırmada aşağıda metnini verdiğimiz 79 ve 80 . sayfalarda yer alan muhammesin birinci, üçüncü ve altıncı bendinin Bursalı Cinânî’nin 5 bendlik muhammesinin birinci, ikinci ve üçüncü bendi olduğu tespit edilmiştir. Bk. Cihan Okuyucu, Cinânî, Hayatı, Eserleri, Dîvânının Tenkidli Metni (Ankara: Türk Dil Kurumu Yayınları, 2011), 249250. Abdurrahman Kâmil'in divançesinde yer alan aşağıdaki muhammesin ikinci, dördüncü ve beşinci bendlerinin Abdurrahman Kâmil'e ait olma ihtimali bulunmakla birlikte, şiirde mahlasın olmaması sebebiyle bu bendlere sadece dipnotta yer verilmiştir.

1

Gördügümde sen gül-i nevreste vü nāzük teni

Artar 'aş়̧̣ım vālih ü dīvāne eylersiñ beni

Açmayup mihr-i ruh-1 zībāñ ç̧eşm-i rūşeni

Kūşe-i firḳatde eylersem 'aceb mi meskeni

Görmemek yegdür görüp dīvāne olmaḳdan seni

2

Dünyeden i' rāż ḳılmaḳdır sebīl-i müttaḳin

Almamaḳdır hāț̣ira aṣlā hevā-yı zỉb ü zīn

Haḳkııma evlā olan olmaḳ durur 'uzlet-güzīn

Bāyezīde gitmemek yegdir benimçün ba' $d$ ezīn

Görmemek yegdür görüp dīvāne olmaḳdan seni 3

'Āşı̧ıa ey māh-rū ' arż eylemekden țal' aṭ̣ñ

'Aş̣k ile mecnūn u şeydā eylemekdir niyyetiñ

Anıñ içün ihtiyār itdim belā vü firkatiñ

Cān u dilden k kat ț idüp recā-yı vușlatıñ

Görmemek yegdür görüp dīvāne olmaḳdan seni

4

Sīnem içre zāhir oldı derd ile et pāresi

İltiyāmı kāabil olmaz vuṣlatınla yāresi

Ag̉lamaḳla ibyiżāza meyl ider göz ḳaresi

Bulunur ancak firāḳıñla bu derdiñ çāresi

Görmemek yegdür görüp dīvāne olmaḳdan seni

5

Hुayli demdir ḩāṭ̂rımda ḳalmadı aṣlā neşāat

Derd-i sīnem olmadı ' ilmiñle cānānım muḥạt

İzdiyād-1 hubbī isterken göründi inhițāt 
168 | A. ERDEMIR / Amasyalı Abdurrahman Kâmil (Yetkin) Efendi'nin Şairliği ve Türkçe Şiirleri

Abdurrahman Kâmil Efendi, eserinde tasavvufî görüşlerini desteklemek üzere muhtelif şairlerin şiirlerinden yararlanırken bazen alıntı yaptığı şairin adını vermekte bazen de vermemektedir. Bazı şiirlerde mahlas bulunmakta, bazılarında bulunmamaktadır. Özellikle beyit halinde yazılmış şiirlerin kime ait olduğunu tespit mümkün olmamaktadır. Bu sebeple eserde başka şairlerden alıntı yapılan mahlassız şiirleri, Abdurrahman Kâmil'e isnad etme yanlışlığına düşmemek için Kâmil mahlası bulunan şiirler çalışmaya dahil edilmiştir.

\section{Abdurrahman Kâmil'in Türkçe Şiirlerinin Şekil ve Muhteva Özellikleri}

Abdurrahman Kâmil Efendi, şiirlerinde Kâmil mahlasını kullanmıştır. Üzerinde çalışma yaptığımız eserde, şairin Kâmil mahlasıyla yazılmış 4 mesnevisi, 2 kasidesi, 1 muhammesi, 1 müsemmeni ve 6 gazeli olmak üzere toplam 14 Türkçe şiiri bulunmaktadır.

Şiirlerde, 7 farklı aruz kalıbı kullanılmış olup iki şiir çift vezinle yazılmıştır. 15 beyitli, I numaralı kasidenin ilk iki beyti ve sonraki beytlerin ikinci misraları, fe'ilâtün fe'ilâtün fe'ilâtün fe'ilâtün kalıbıyla; geri kalan 13 beyitin birinci misraları ise fe'ilâtün fe'ilâtün fe'ilâtün fe'ilün kalıbıyla; 15 beyitli 2 numaralı kasidenin ilk mısraı hariç diğer misraları fácilâtün/ fầ ilâtün/ fấilâtün/ fấilün,

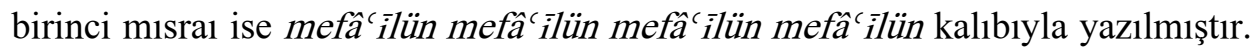
Bir şiirin iki farklı vezinle yazılması, klâsik Türk şiir geleneğinde ender rastlanan bir durumdur.

Türkçe şiirlerde kullanılan aruz kalıpları ve nazım şekillerine ${ }^{28}$ göre şiir numaraları şöyledir:

\begin{tabular}{|c|c|}
\hline Kalıplar & Şiirlerin nazım şekli ve şiir numarası \\
\hline fâc ilâtün fâc ilâtün fâc ilâtün fâc ilün & K2, MU1, G1, G2, G4, G6 \\
\hline 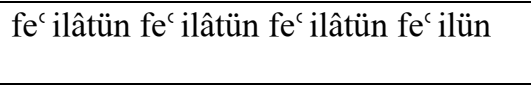 & $\begin{array}{l}\text { MÜ1, G5 ve K1'in üçüncü beyitten } \\
\text { itibaren birinci misralar1 }\end{array}$ \\
\hline müfte ${ }^{c}$ ilün fấ ilün müfte ilün fầ ilün & $\mathrm{M} 2, \mathrm{M} 3$ \\
\hline fâc ilâtün fấ ilâtün fâc ilün & M1 \\
\hline
\end{tabular}

Görmemekçün meh yüzüñ dostlarla itmem ihtilāt Görmemek yegdür görüp dīvāne olmaḳdan seni

6

İstemez dil kūyüñe varup 'azīmet ḳılmag̉a

Mūnis olmuşdur ḩayāliñle ḳanā' at ḳılmag̉a

Çāre yoḳdur gerçi vaṣlıñdan ferāgat ḳılmag̉a

Vechi var ḳașd eylesem hecriñle ülfet ḳılmaga

Görmemek yegdür görüp dīvāne olmaḳdan seni

28 Şiirlerin nazım şekillerinin kısaltması şu şekilde verilmiştir: G: Gazel, K: Kaside, M: Mesnevi, MU: Muhammes, MÜ: Müsemmen. 
A. ERDEMIR / The Poetry Skill and the Turkish Poems of Abdurrahman

Kâmil (Yetkin) Efendi From Amasya | 169

\begin{tabular}{|c|c|}
\hline mefấ îlün mefấc îlün fe $\mathrm{fe}^{c}$ ülün & M4 \\
\hline mefâc îlün mefấ îlün mefấc îlün mefấc îlün & G3 ve K2'nin sadece birinci mısra1 \\
\hline $\mathrm{fe}^{\mathrm{c}}$ ilâtün $\mathrm{fe}^{\mathrm{c}}$ ilâtün $\mathrm{fe}^{\mathrm{c}}$ ilâtün fe ilâtün & $\begin{array}{l}\text { K1'in ilk iki beyiti ve sonraki beyitlerin } \\
\text { ikinci misraları }\end{array}$ \\
\hline
\end{tabular}

Şair, vezin kullanmada genel olarak başarılı olmakla birlikte, zaman zaman uzun okunması gereken heceyi kısa okuyarak zihaf yapmış; bazen de medli olduğu için bir buçuk hece okunması gereken kelimeleri bir hece okumuştur. Şair, müfte`ilün fấilün müfte`ilün fấilün vezniyle yazılmış olan aşağıdaki beytin birici mısraındaki -mek hecesinde kapalı heceyi açık okuyarak zihaf yapmış; aynı mısradaki bïh kelimesini de iki hece okuması gerekirken tek hece okumuştur.

Eylemek teşbīh hațā serve anıñ boyını

Kim degişür ' anbere ruhlarınıñ būyını (M2/2)

Aynı şiirin aşağıdaki beytinin birinci mısraında hiç kelimesi bir buçuk (medli) okunması gerekirken tek hece okunmuştur. İkinci mısrada reşkden kelimesindeki -den hecesi kapalı olmasına rağmen zihaf yapılarak açık okunmuş; ikinci misradaki kapkara kelimesindeki $-k a$, ve $i k i$ kelimesinin ilk hecesi olan $-i$ hecesi ve yüzi kelimesinin ikinci hecesindeki -zi hecesi kısa (açı) olmasına rağmen imâle yapılarak uzun (kapalı) okunmuştur. Şüphesiz burada asıl sorun imâleler değil meddin gözden kaçırılması, daha da önemlisi, sonu sessiz harfle biten bir hecede zihaf yapılmış olmasıdır.

Vașfinı tahrīre yok țâkatı hiç ḩāmeniñ

Reşkden ḳapkaradur ıki yüzi nāmeniñ (M2/6)

Aşağıdaki beyitin ilk mısrasındaki hıyâr kelimesinin ikinci hecesi olan -yâr hecesi, kural gereği medli olarak iki hece (kapalı açık) okunması gerekirken tek kapalı hece olarak okunmuştur. İkinci mısradaki istemeyüp kelimesinin ikinci hecesindeki açık -te hecesi, kanda kelimesindeki -da hecesi uzun (kapalı) okunmuş ve imâle yapılmıştır. Kâmilâ kelimesindeki -lâ uzun hecesi de zihaf yapılarak kısa okunmuştur:

İşte ' inān-1 ḩıyār çı̣̣dı elimden bu dem

Vaṣlını istemeyüp Kāmilā ḳanda gidem (G1/7)

Abdurrahman Kāmil Efendi'nin şiirlerinde karşılaştı̆̆ımız ve bizim yukarıda ifade ettiğimiz aruz kusurlarının çoğu, zamanla değişerek oluşan Türk aruzunun $^{29}$ onun şiirlerine yansımasıdır. Medli okunması gereken kelimelerin

29 Türk Aruzu konusunda geniş bilgi için bk. M Fatih Köksal, Son Dönem Divan Şairlerinden Kütahyalı Vasfî Dîvânı (İstanbul: Kesit Yayınları, 2016), 31-37. 
170 | A. ERDEMIR / Amasyalı Abdurrahman Kâmil (Yetkin) Efendi'nin Şairliği ve Türkçe Şiirleri medsiz okunması, bazı Arapça kelimelerde geçen ünsüzlerde Türkçe söyleşişin esas alınması, şairin dikkat çeken aruz tasarruflarıdır. Aşağıdaki mısrada şair, normalde ayın harfi ünsüz olduğu için 'azm hecesini kapalı okuması gerekirken kelimenin Türkçe söyleyişini esas alarak bunu açık hece gibi düşünmüş ve önceki kelimenin son hecesine ulama yapmakta beis görmemiştir:

Kendim 'azm itsem eger şimdi țaḳup boynuma țavḳ (MÜ/2/1)

Abdurrahman Kâmil Efendi'nin elif-nâme ${ }^{30}$ tarzında yazılmış bir kasidesi vardır. Kâmil Efendi, elif-nâmesinde, Arap alfabesindeki elif'ten ye'ye 29 harfle birer mısra yazmıştır. Şiirde harfler vezne dâhildir.

Abdurrahman Kâmil Efendi şiirlerinde sen bilin, bunca hukukun olması gibi yerel söyleyişlere de yer vermiştir:

Ey șabā sen biliñ ol yār ile var bunca ḥuḳụ̄

Yüz süre pāyiñe var hālimi ' arż eyle çabuḳ (MÜ/2/3-4)

Abdurrahman Kâmil'in şiirlerinin konusu ilâhî aşktır. Şiirlerinde coşkun bir lirim hâkimdir. O, divan şairlerinin idealize edilmiş bir güzele aşkını ifade etmek için kullandığg kelimeleri, tasavvufî manada kullanmıştır.

İlk mesnevi 19 beyit olup aynı zamanda eserin de ilk şiiridir. Şiir, işe besmeleyle başlamanın önemine vurguyla başlıyor:

Şaire göre besmele, aşk ehlinin tesbihidir. Besmelesiz söze velvele denir. Besmele her işe anahtardır. Besmelesiz her işin ayağı baltaya uğrayacaktır:

Ehl-i ' aşk tesbīhidür çün besmele

Besmelesiz söze dirler velvele

Besmele miftāḥdur her pişeye

Ansız işiñ pāyı uğrar tīşeye (M1/4,5)

Besmeleden sonra Allah'a hamd edilmelidir. Çünkü o bize lisanla süs ve güzellik verdi. Kim Allah'a hamd ederse, Allah ona yardımını ulaştırır. Hamd her zaman nimeti artırır; dostu memnun, düşmanı mahzun eder:

30 Elif-nâme; "Misra, beyit veya dörtlüklerin ilk harfleri ya da son harfleri alt alta getirildiğinde elif'ten ye'ye kadar alfabetik bir biçimde siralanan ya da bir baştan bir sondan harflerin alınmasıla oluşturulan; kimi zaman da Arapça'da bulunmayan p, ç ve $j$ harflerinin de içinde bulunduğu; ăğrlıkl olarak gazel, kaside, mesnevi, murabba', muhammes, müseddes, tercî'-i bend gibi farklı nazım sekilleriyle yazılabilen daha çok dînîtasavvufí ve didaktik konulu olmakla birlikte çeşitli konularda örnekleri olan manzumelerdir." (Mehmet Arslan, "Mihrî Hâtun Divanı'nda Sanatlı Manzumeler", Uluslararası Amasya Âlimleri Sempozyumu Bildiriler Kitab1 2(21-23 Nisan 2017) (Ankara: KIBATEK, 2017), 2: 30). 
Huāliḳa ḥamd eyleyelim bac $d$ ez-īn

Çün bize virdi lisānla zīb ü zīn

Ḥamd-i Ḥaḳkı kim ki eylerse edā

İrgürür in`āmın aña ol Hुudā

Ḥamd her dem ni` meti efzūn ider

Dostı memnūn düşmeni maḩzūn ider (M1/6-8)

Şair, daha sonra varlıkların en hayırlısı Hz. Muhammed'e, ailesine, ona yardım edenlere, özellikle seçkin dostları olan dört halifeye sayısız salat ve selam gönderir. Çünkü onlar; âşıkların öncüsü, Allah'ın sevgilisi Hz. Muhammed'in dostlarıdır. Onlar, bir nefes bile olsa onun yanından ayrılmadılar. Bu sebeple hep hayırla anılırlar:

Bì-` aded olsun șalātile selām

Ol resûle kim odur hayrü'l-enām

Āline olsun selām enșāinna

Bā-ḥușūṣ ol dûstān-1 çārnna

Bil olardur ' āşıḳānıñ aḳdemi

Ya' ni mạ̣būb-1 Hudānıñ hem-demi

Bir nefescik olmadılar gayr ile

Bu sebebden yād olurlar hayr ile (M1/11-14)

Abdurrahman Kâmil, ehl-i sünnet yolunun yolcusudur. O, ashabın yolundan giderek hedefe yol bulunacağına inanır. Bu sebeple kendisine seslenen şair, "Ey Kâmil, ashabın izinden yürü, ehl-i sünnet mezhebinin yolcusu ol." der:

Meslek-i aṣhạāba iden iḳtidā

Bāb-1 makșūda bulur ol ihtidā

Kāmilāașhāāb izinde peyrev ol

Ehl-i sünnet mezhebinde reh-rev ol (M1/18,19)

Şair, divan şiiri geleneğinin mazmunlarına vâkıf olup, bu mesnevide divan şiirinin sevgiliye ait benzetme unsurlarını kullanmaktadır. Öğütle meşgulken onun gönül çocuğunu, benzerini daha önce görmediği bir güzel kapmıştır. Öyle ki bu 
172 | A. ERDEMIR / Amasyalı Abdurrahman Kâmil (Yetkin) Efendi'nin Şairliği ve Türkçe Şiirleri sevgilinin boyu serviden daha güzel olduğu için onu serviye benzetmek hatadır. Yanaklarının kokusunu kimse anbere değişmez. Onun dişine Aden incisi, kaşına Yemen kılıcı dense yeridir:

Pend ile meşğūl iken ḳapdı gönüül țıflını

Bir güzeliñ hüsni kim görmemişem mișlini

Eylemek teşbīh hațā serve anıñ boyını

Kim degişür ' anbere ruhlarınıñ bûyını

Dürr-i ' aden dişine dinse sezādır sezā

Kaşıına seyf-i Yemen dinmege ġāyet be-câ (M2/1-3)

Abdurrahman Kâmil Efendi, dördüncü sıradaki 55 beyitlik mesneviyi, Amasya merkeze bağlı bugünkü adıyla Şeyhsadi köyünde medfun bulunan Şeyh Şâdî Hazretlerine olan muhabbetini ifade için yazmıştır.

Tasavvufî tarzda şiirler yazan Kâmil Efendi’nin bu mesnevisi, onun divan şiiri geleneğini ve yaygın benzetme unsurlarını şiirde nasıl kullandığını somutlaştırması bakımından önemlidir. Kâmil Efendi, mesnevide Şeyh Şâdi’ye muhabbetini ifade ederken sanki divan şiirinin güzeline seslenmektedir. Sevgili sultandır ve sevgilinin kaşı tuğraya, saçı sünbüle, yanağı güle, beni karabibere, dişi inciye, dudağı yakuta, teni gümüşe, boyu salınan serviye benzer. $O$, gönül aldatır, gönül çalar:

Sefer-nāme yaz ey ḩāme o şāha

Kaşı tụgrā başı zerrīn-külāha

Șaçı sünbül dili bülbül edỉbe

Ruhı gül hāli fülfül dil-firībe

Dişi incü lebi yāḳūt-fāma

Teni sīmin boyı serv-i ḩırāma (M4/1-3)

Aşkın kaynağı ezel meclisidir. Temiz aşk, ezel meclisinde icat olmuştur. Kâmil'in alnına aşk tuğrası bu mecliste yazılmıştır. İlâhî aşka mecaz köprüsünden geçmeden ulaşılmaz. Onun için aşk fetvası, "Mecaz köprüsünden geçmeden ilahî aşka ulaşılmaz." diye yazılsa yeridir:

Şol ezel bezminde kim ìcâd olundı ' aşk

Cebheme imlā olındı ey göñül tụğrā-y1 ' aşḳ (G2/ 2) 
Geçmeden cisr-i mecâzı hâșıl olmaz' aşḳ-1 Haḳ

Böyle yazılsa be-cādır ey gönül fetvā-yı ' aşk (G2/7)

Kâmil Efendi şiirinde, sevgili-rakip ilişkisi içinde toplumsal eleştiriye de yer vermektedir. Güzeller artık sîm ü zer peşindedir. Âşı̆̆ın sevgiliye ulaşmasının yolu ne sihir ne büyüdür. Sevgiliyi rakipten ayıracak, âşıka yaklaştıracak en tesirli ilaç altın ve gümüştür. Onu hangi sevgiliye versen sînebendini hemen çözer. Sevgiliye kavuşmada en tesirli ilacın altın ve gümüş olduğunu bilen şair, yazı ipliğine altın, gümüş ve inci dizer. Bilir ki o zalim sevgili lutfedip bir baksa, bu yazı ipliğine dizilmiş inciyi görür, derhal rakibi terk ederek Kâmil'in tarafına geçer:

Dilberi celb eylemekse niyyetiñ ' āşık eger

Siḥr ü efsûn zaḥmetiyle zāâtıña virme żarār

Bul anı kim yāri celb ag̉yārı hem tefrīk ider

Bir mü 'essir nüsḩadır kim nâmı anıñ sīm ü zer

Kanḳı maḥbūba virürseñ sīne bendin tīz çözer (T1/1.Bend)

Rişte-i taḥrīe Kâmil sīm ü zerle dür düzer

O cefā-pīşe eger luṭf eyleyüp itse naẓar

Terk idüp aġyārı derḥâl sūyuma eyler güzer

Bir mü 'essir nüshadır ki nâmı anıñ sīm ü zer

Kanġ1 maḥbūba virürseñ sīne bendin tīz çözer (T1/6.Bend)

Coşkun bir lirizmle ayrılık duygusunu ve sevgiliye kavuşma arzusunu ifade eden şair, müsemmen nazım şekliyle yazdığ 1 şiirinin bir bendinde, saba rüzgârını haberci yapar ve sevgiliye gönderir; "Benim katlime ferman ne imiş, canımı istemede sevgilinin kasdı ne imiş, rakibin köyünde bize atılan iftira ne imiş, bir iki gün verse de katlime meydan ne imiş, var ögren; eğger kendi benim canımı isterse, onun için bir can ne imiş, cânânıma cânımı kurban etmek ne imiş, onu da söyle. O hiç zahmet çekmesin ben kılıcımı çekeyim kendime kendim vurayım ve canımı cananıma bir haberci ile tezce göndereyim." der:

Var șabā șor bu benim ḳatlime fermān ne imiş

Cānımı istemede makṣad-1 cānān ne imiş

Görelim kūy-1 ' adūda bize bühtān ne imiş

Virse de bir iki gün ḳatlime meydān ne imiş

Kendi isterse eger cānımı bir cān ne imiş

Eylemek cānımı cānānıma ḳurbān ne imiş 
174 | A. ERDEMIR / Amasyalı Abdurrahman Kâmil (Yetkin) Efendi'nin Şairliği ve Türkçe Şiirleri

Çekeyim tïgımı ben kendime kendim urayım

Cānı cānānıma bir peyk ile tĩz göndereyim (MÜ1/4.Bend)

Kâmil Efendi, of redifli bir şiirinde, sevgiliden ayrı kalmanın hüznüyle feryat etmekte ve ömrünün en güzel yıllarını rüzgâra verdiği için of çekmektedir. $\mathrm{O}$ artık bu dünyada vuslatın gerçekleşmeyeceğine inanır. Cismim ve tenim ayrılık ateşiyle yandı. Hiç olmasa mana âleminde sevgiliye kavuşsaydım, diyerek âh eder, of çeker:

Of yārdan ayrilıkla itdigim feryāda of

Virdigim mahṣûl-i ‘ ömr-i nâzenīni bāda of (G4/1)

Āteş-i hicrânda yandı Kāmilā cism ü tenim

Āh vuṣlat eyleseydim yāre tek ma'nāda of (G4/5)

\section{Sonuç}

Soyu Amasya'da Mecdîzâdeler olarak tanınan bir aileye dayanan Abdurrahman Kâmil Efendi, 1850 yılında Amasya'da doğmuş ve 1941'de Amasya'da vefat etmiştir.

İyi bir dinî eğitimden sonra, Amasya Sultan Bayezid Camii kürsü şeyhliği ve uzun yıllar Amasya müftülüğü yapmıştır. Kâmil Efendi'nin ilmî şahsiyeti ve millî mücadeledeki rolü ile ilgili günümüze kadar çok sayıda çalışma yapılmış; şiirleri ve şairliği üzerinde durulmamıştır.

Abdurrahman Kâmil Efendi'nin şiirlerinin tespitinde, Milli Kütüphane Yazmalar Koleksiyonu Yz. A 8993 numarada, Divançe ismiyle kayıtlı meellif hattı nüsha esas alınmıştır. Eser, manzum-mensur karışık olarak yazılmış; mensur kısımlarda ifade edilen tasavvufî düşünceler, Türkçe, Arapça ve Farsça şiirlerle desteklenmiş; şiirler konuya uygun olarak mensur kısımlar arasına serpiştirilmiştir.

Bu çalışmayla Abdurrahman Kâmil Efendi'nin Kâmil mahlasıyla yazdığı 14 Türkçe şiirinin bulunduğu despit edilmiş ve bu şiirlerin çeviriyazısı yapılmıştır. Şiirlerin 4'ü mesnevi, 2'si kaside, 1'i muhammes, 1'i müsemmen ve 6's1 gazel nazım şekliyle yazılmıştır. Şiirlerde, 7 farklı aruz kalıbı kullanılmış olup iki şiir, klâsik şiir geleneğinin dışında çift aruz kalıbı ile yazılmıştır.

Şair, genelde aruz veznini kullanmakta başarılı olmakla birlikte şiirlerde yer yer zihafla karşılaşılmaktadır. Yine şiirlerde bîh, hîç, yâr ve tîz gibi biri kapalı, biri açık olmak üzere iki hece (medli) okunması gereken kelime ve heceler tek kapalı hece olarak okunmuştur. 
Abdurrahman Kâmil'in şiirlerinin konusu ilâhî aşktır. O, şiirlerinde divan şairlerinin idealize edilmiş bir güzele aşkını ifade etmek için kullandığı kelimeleri, tasavvufî manada kullanmıştır. Şiirlerinde coşkun bir lirizm hakimdir.

Oğlu Ahmet Emrî Yetkin, babasının kendi şiirlerinin bir kısmını imha ettiğini, bir kısmının ise kaybolduğunu söylemektedir. Şairin şiirlerini niçin imha ettiği bilinmiyor. XX. yüzyılda, XVI. yüzyıl klâsik şiir geleneğinin takipçisi olan Abdurrahman Kâmil'in şiirlerinin imhası şüphesiz büyük bir kayıptır. Kaybolan şiirlerin bulunması ve neşri ise onun şiirleri ve şairliği hakkında daha sağlıklı değerlendirme yapılmasını sağlayacaktır. 
176 | A. ERDEMIR / Amasyalı Abdurrahman Kâmil (Yetkin) Efendi'nin Şairliği ve Türkçe Şiirleri

\section{AMASYALI ABDURRAHMAN KÂMIL EFENDI'NIN TÜRKÇE ŞIIIRLERİ}

MESNEVILER

1. MESNEVĩ $\overline{\tilde{I}}^{31}$ s.2, 86b, 81

făcilātün/ făcilātün/ fă‘i ilün

Mațla' -1 envâr-1 Kur ân-1 Kerīm

Oldı Bismillahirraḥmânirraḥim

Başla ey dil sen anıñla bu işe

'Avn-i ḥaḳla tā ḥıtāma irişe

Maḳsadıñ ḳoşdur aña rīş oldı o

Kuş ḳanadsız uçsa olur ser-fürū

Ehl-i ‘ aşk tesbīhidür çün besmele

Besmelesiz söze dirler velvele

5 Besmele miftāḥdur her pişeye

Ansız işiñ pāyı uğrar tişseye

Huâliḳa hamd eyleyelim ba'd ez-īn

Çün bize virdi lisānla zīb ü zīn

Ḥamd-i Haḳkı kim ki eylerse edā

İrgürür in` āmın aña ol Hुudā

Hamd her dem ni` meti efzūn ider

Dostı memnūn düşmeni maḩzūn ider

$31 \mathrm{Bu}$ mesnevi, yazma nüshanın 2,81 ve $86 \mathrm{~b}$ sayfalarında yer almaktadır. $81-86 \mathrm{~b}$ arası sayfalar, eserin gözden geçirilmiş farklı bir nüshasının ilk sayfalarının nüshaya sonradan karışık bir şekilde yapıştırılmış halidir. Yukarıdaki şiir, ikinci sayfada yedi beyit iken, nüshaya sonradan eklenen bir sayfa olan 86b'de 17 beyittir. Yaptığımız incelemede, yazma nüshada $86 \mathrm{~b}$ olan sayfanın devamının 81.sayfa olarak metne sonradan yapıştırıldığ tespit edilmiş̧; 86b'de 17 beyit olarak verilen mesnevinin devamı olan iki beyitin 81. sayfada olduğu görülmüştür. Şairin mahlasının da bulunduğu sayfa 81 'de yer alan bu iki beyit mesneviye eklenmiştir. 
Re 's-i şükr oldı ḥam(i)d bī-iştibāh

Bu söze ḳavl-i resūl-i Hạ güvāh

10 Hamd ile mevșūf olan maḥmūd olur

$\mathrm{Ni}^{`}$ meti bol sofrası memdūd olur

$B \bar{i}^{-}{ }^{`}$ aded olsun șalātile selām

Ol resūle kim odur ḩayrü'l-enām

Āline olsun selām enșārına

Bā-ḥuṣūṣ ol dūstān-1 çārına

Bil olardur ' āşıḳānıñ aḳdemi

Ya' ni maḥbūb-1 Hudūānı̃ hem-demi

Bir nefescik olmadılar gayr ile

Bu sebebden yād olurlar hayr ile

15 Hayr ile añ hem-dem-i peygamberi

Tā olasın bu cihānıñ ser-veri

Kim ki sevmez anlarıñ bir ferdini

Dūzaḩ içre artırır hak derdini

Kim ki uyar dār-1 āḩret şāhına

Hịç baḳar mı işbu dünyā cāhına

(s.81) Meslek-i aṣhāba iden iḳtidā

Bāb-1 makṣūda bulur ol ihtida

Kāmilāașhāb izinde pey-rev ol

Ehl-i sünnet mezhebinde reh-rev ol 
178 | A. ERDEMIR / Amasyalı Abdurrahman Kâmil (Yetkin) Efendi'nin Şairliği ve Türkçe Şiirleri

2. MESNEVİ s.4-5

müfte`ilün/ fă‘ilün/müfte`ilün/ fă‘ilün

Pend ile meşḡūl iken ḳapdı göñül țıflını

Bir güzeliñ hü̈sni kim görmemişem mișlini

Eylemek teşbīh hațāa serve anıñ boyını

Kim degişür ' anbere ruhlarınıñ būyını

Dürr-i ' aden dişine dinse sezādır sezā

Kaş̧ına seyf-i Yemen dinmege gāàyet be-cā

Zülf ile setr eylese rūy-1 kamer tābını

Zulmet içinde ḳoyar ḳaşları mihrābını

Medrese-i ' aşḳda cem` olup ehl-i ' uḳūl

Meś’ele-i zülfiniñ ḥalline bulmadı yol

Vaṣfını taḥrīe yok țāḳatı hīç hāameniñ

(s.5) Reşkden ḳapḳaradur iki yüzi nāmeniñ

İşte ' inān-1 hyıār çı̣̦dı elimden bu dem

Vaṣlını istemeyüp Kāmilā ḳande gidem

\section{MESNEVĪ s.50-51}

müfte'ilün/ fācilün/müfte'ilün/ făcilün

Aldım ele nāmeñi baş ayaḳ itdüm naẓar

Dildeki āteşiñe haylice itdim keder

Hāeecigim bac $d$ ez-īn ben seni itmem hazīn

Hidmet ile zātıña göñlüñ idem zīb ü zīn

Āteş-i firḳat ile cān u diliñ yaḳmazam

Her kişiniñ pāyına șu gibi ben aḳmazam

Kūşe-i hicrānda hāạtırın itmem ḩarāb

Her söziñe virmezem ba' demā acı cevāb 
5 Şem ${ }^{c}$-i ruhumdan imiş rūz şeb tāb-1 diliñ

Şevk ile maḩlūt imiş añladım āb u giliñ

Șidḳda mümtāzsıñ şevḳda serbāzsı̃̃

Ṭutmada her emrimi ' āşıḳ-1 bī-nāzsı̃

Bu gice teşrīf idem külbe-i ahzzānıñı

Vaṣl ile ābād idem hem dil-i vīrānıñ

Hậl-i diliñ șorayım pāyiñe yüz süreyim

Âteş-i ḥasret ile niçedir ol göreyim

Tā ki hulūṣ-1 diliñ Kāmil idem özüme

Baḳasın leyl ü nehār yüzüme hem gözüme

\section{MESNEVĪ s.93-98}

mefā'ilün/mefā'î̉ün/fe' ūlün

Sefer-nāme yaz ey ḩāme o şāha

Kaşı tuggrā başı zerrīn-külāha

Șaçı sünbül dili bülbül edībe

Ruhıı gül hāali fülfül dil-firībe

Dişi incü lebi yāḳūt-fāma

Teni sīmin boyı serv-i hırāma

Yüzi rengīn sözi şīīin emīre

Semāḥat menba' 1 rūşen-żamīre

5 Hümā-țāl' at ḳamer-behcet civāna

(s.94) Sa Sa ādetlü hạabīb-i c āli-şāna

Huyı hūb imtizācı nerm-i nerme

Güneş yüzli mizācı germ-i germe 
180 | A. ERDEMIR / Amasyalı Abdurrahman Kâmil (Yetkin) Efendi'nin Şairliği ve Türkçe Şiirleri

Emānet it yed-i peyk-i șabāya

İrişdirsün maḳām-1 dil-güşāya

Te 'eddüble gire bezm-i ' alāya

Niçe ta' zaim ide ol yüzi aya

Yüzin süre ḳadem-gāha edeble

Yakīin ola o māha bu sebeble

10 Atınca semtine ol yār țarfi

Küşād ide hemān-dem ẓarf-ı ḥarfi

İde bu nāmeyi bir bir ḳırā 'at

İşide baş ayaḳ ol serv-ḳāmet

Sütūr-1 nāme bulduḳda hitāmı

Muhạbbet būyın aldıḳda meşāmı

Șorarsa ḥāl-i ' aşḳ̂ ol dil-ārā

İderse zulmden artı̣̣ tevellā

Disün ol nāzenīn-i ḩoş-edāya

Firāḳıñ ḳaddini döndirdi yāya

(s.95) Gezerken zīr ü bālāyı te 'essüf

15 Atıldı bi 'r-i hicrāna çü Yūsuf

Cüdā düşdi diyārından o maḥzūn

Firāḳıñla dü çeşminden aḳar hūn

Yüziñe baḳmaġa toymazken aḳdem

Selāma muntaẓırdır şimdi her dem

Mürūr idinceye dek tā ag̉ustos

Tolandırdı anı hecriñ çü fānūs 
Ḥulūl itdi şu günde māh-1 eylül

Olur elbet haber gelmezse ma' lūl

20 Cemāliñ fikr idüp işin unutdı

Cefā defterlerin dürdi de yutdı

Seni görmezse olur mı o handān

Olur elbet bu dünyā aña zindān

Dil-i vīrānı ābād it sözüñle

Dü çeşmin rūşen ü şād it yüzüñle

Gelürseñ bezmine ey serv-i bālā

'Aceb dir mi seniñ emriñe lā lā

Görürse ḳadd-i țābāñn a şimşād

(s.96) Dırahtt-1 servi eyler mi dili yād

25 İderseñ vașl ile göñlin ' imāret Kamu hū̄bāna eylersiñ imāret

Alursañ ' āşıḳı zīr-i cenāha İrersin şübhesiz evc-i necāḥa

Açarsañ māh-rūyüñden niḳāb1

Ara yirden götürürsüñ hịcāb1

Hulūṣāne açar ag̉zın du āya

Atar tîr-i senāyı tā semāya

Ḳyupdur ugiruña o cān u baş1

Aḳar dā'im seniñçün gözi yaşı

30 Çün old1 ' aḳlı zülfüñ tek perişāan

Gezer Ferhād gibi țag̉da yemez nān 
182 | A. ERDEMIR / Amasyalı Abdurrahman Kâmil (Yetkin) Efendi'nin Şairliği ve Türkçe Şiirleri

Gezerken vardı Şeyh Şādī köyine

Derūnı āteşi belki söyine

Naṣılsa gün-be-gün artdı ḥarāret

İçinden țı̧ına urdı merāret

Gice gündüz füzūn oldı bükāsı

Gözi yaşıyle tọoldı müttekāsı

(s.97) Bu hạālde gördi şeyhiñ ḳabr-i pākin

Gözine sürme ḳıldı hāak-i pākin

35 Elif ḳaddini sīmīn dāl ḳıldı

Deri halḳasına tims̄āl ḳıldı

Türābın öpdi bed 'itdi senāya

Șanevber gibi el açdı du` āya

Didi yāriñ derinde bende olsun

Cihān serverleri efgende olsun

Hemișe bedr-i hüsni bula pertev

Mehābīb-i zamāna ola hüsrev

Ola bahtım vișāliyle huceste

Kelāmıyle ola her gusșșa beste

40 Çerāg

Bahār-1 hüsnünüñ dīvānesiyim

N'ola bir șorsa hạāl-i pür-melālim

Düşer mi pāyesinden pür-kemālim

Mesākīn hāạtırın itmek ric āyet

Degil mi ' izzet ehline ' alāmet 
Kadem rencīide ḳılsun o şehen-şāh

(s.98) Buyursun hücreme ol ruhları māh

Oțam içre żiyā virsün çü hưrşīid

Buyursun şevḳimi vuṣlatla te 'kīd

45 Leb-i ruhsārını gözden geçürem

Aña da bāde-i ' aşḳı içürem

Koyam evrāḳımı iki cebine

Merāmım 'arż idem ol meh-cebīne

Şeb ü rūz bāg̀-1 vașlına gireyim

Dem-ā-dem mīve-i hüsnin direyim

Țolaşam çār ețrāfın dem-ā-dem

Yiyem hem dāne-i rūyin çü Ādem

Șorayım leblerin yüzin göreyim

Gözine yüzümi bir dem süreyim

50 İki ellerini alam dü deste

Okuyam her birine niçe beste

Kemer gibi șarılam mū miyāne

Diyem ḥāim aña ben yāna yāna

Teraḥhum eyleye bu pür-melāle

Döküp ḳanım ulaşmaya vebāle

Göñül ta'mīir iden 'ālī-nesebdir

Hुarāb iden hakạiḳat bī-edebdir

Yüzin görmek dilerse Muṣtafānıñ

Yüzime açsun ebvābın șafānıñ 
184 । A. ERDEMIR / Amasyalı Abdurrahman Kâmil (Yetkin) Efendi'nin Şairliği ve Türkçe Şiirleri

Hulāṣā Kāmihñ meyli vefāya

Marī̇̇ir țāḳatı yoḳdur cefāya

\section{KASTīDELER}

\section{KASTīDE ${ }^{32}$ s.7-9}

fe'ilâtün/ fe'ilātün/ fe'ilātün/ fe'ilātün

fe'ilātün/ fe'ilātün/fe'ilātün/fe'ilün

Yine medh eyleyeyim bir güzeliñ hüsn-i cemālin

İşiden añlaya ol gül-bedeniñ ḳadr ü kemālin

Öyle bir pāk aṣıl pāk nesil ḩāk-nihādı

Ṭuysa 'uşşāḳ-1 zamān ḩ̌āhiş ider bū-yı vișālin

' Āşı̣̂-1 hüününi gördükde mükedder o perī

İltifātile dilinden siler elbette melālin

(s.8) Niçedir ḥāl-i diliñ āteş-i ‘ aşḳımla benim

Diyerek ' arż ider āşüftesine gunc ü delālin

5 Mā'ilim işvesine nāzına el-ḥaḳ cāndan

Gūş-1 cān diñlemek ister anı̃ ol țatlı makāāin

Rūy-1 gül-būyını keşf eylese bir meclis-i ' ‘ işe

Der-`aḳab terk ḳılar ehl-i cüdā ceng ü cidālin

Șalamaz seyr-i cihāna gözüni dem-be-demi

Kim ki `ömründe görüpdür o müzeyyen ḩat u hāalin

Mest-i lā-ya' ḳ1l olur nūş iden ol hamr-1 lebin

Hīç ayılmaz dünyeniñ içse de biñ āb-1 zülalin

$32 \mathrm{Bu}$ kaside iki farklı aruz kalıbıyla yazılmıştır. Kasidenin üçüncü beyitten itibaren birinci mısralarında féilātün/fe'ilātün/fe'ilātün/fe'ilün kalıbı kullanılmıştır. 
Öyle bir ‘ ārif ü dānā-yı sühandır bu güzel

Fehm ider niçe rumūzuñ bir tefekkürde me'ālin

10 Nükte-dānlıḳda Fużūli gibi māhir erdir

Żabṭ ḳılmış bu cihānıñ hemān ol siḥr-i hẹelālin

Bir nefes görse idi vech-i vecihin $\operatorname{Nef}^{\Upsilon} \bar{i}$

Anı medḥ itmege hașr eyler idi cümle maḳālin

Huūb-rūyān-1 zamāna baḳabilmem aṣlā

Göze göz dir mi 'aceb seyr iden ol çeşm-i gazālin

Cismi cismim gibidir lạ̣mi de lạ̣mim gibice

(s.9) Hüsnüne kim baḳanıñ isterim elbette zevālin

Anıñ evsāfinı taḥrīi idebilmez huāme

Ehl-i 'aş̣ ' add idebilmez anıñ ol hūūb ḩıșālin

15 Reh-i şevḳında bulunca bu kemāli Kāmil

Cāygīi eyledi göñlünde anıñ ' aşk u ḩayālin

2. $\mathrm{KASTīiDE}^{33}$ [ELIF-NĀME] (s.47-49)

fá ilātün/ făcilātün/ făcilātün/ fă iliün

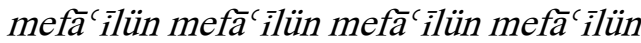

(Elif) āmāl-i dünyā riştesin ḳaț eyledim cānā

(Bā) binā-yı aşḳa șarf itdim ḳamusın meh-liḳāa

(Tā) teraḳkị eyledim emsālime leyl ü nehār

(S̄ā) șenālarla ḳılındım vaṣlıña yārā sezā

(s.48) (Cīm) cenābıñ ḩıdmetiyle kesb-i taḥșīl eyledim (Ḥ̂ā) ḥużūrundan dil-ārā nice dürlü kīmyā

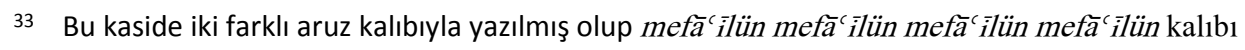
sadece birinci mısrada kullanılmıştır. 
186 | A. ERDEMIR / Amasyalı Abdurrahman Kâmil (Yetkin) Efendi'nin Şairliği ve Türkçe Şiirleri

(Hāa) h̆ıīiv-i Miṣr-1 dille şöhretiñ buldı şuyū

(Dāl) dilim şehrin vișāliñle idince sen küşā

5 (Z̄āl) zekāvetle olursuñ vāṣıl-1 cümle fünūn

(Rā) rikābın būs ider Soḳrāt-1 hịmet-āşinā

(Zā) zekāt-1 vuṣlaṭıñla bay idersiñ ‘āşıḳıñ

(Sīn) seherler ' izzetiñçün eylerim niçe $d u^{\prime} \bar{a}$

(Şîn) şaḳk itseñ dehānı porsiş-i hāạtır için

(Șād) șanurdum Üsküdārı baña virdiñ gūyiyā

(Dād) ḍa î if ḳılma bu cismim kūşe-i hicrānda

(Tāa) țayanılmaz belādır tọgrisı bu mācerā

(Z̄ā) zarāfet ma' deni bir dem baña rạ̣m eyleseñ

('Ayn) 'aşḳ̂ñdan Hudāya itmezem hịç iştikā

10 (Ġayn) gamzeñle bu şīīin cānıma ḳaṣd eyleseñ

(Fā) firār itme cibāl-i firḳata aṣlā şehā

(Kāâ) k̦arīb olmaḳ içün dergāhıña rūz [u] şebān

(Kāf) kelāmım ṣırasın șarf eyledim çün āsiyā

(Lām) levm itme ta' aşşuk itdigümçün çeşmiñe

(s.49) (Mīm) merāḳı tā ezel virdi baña ol kibriyā

(Nūn) nāmūsı bıraḳdırdı baña şevḳ-ı cemāl

(Vāv) vașl-1 rūy-1 āliñ eylerim her dem recā

(Hā) hevādārān-1 aṣra pīşvā olup da sen

(Lām elif) lā deyu i`rāż eyleme benden dilā

15 (Yā) yürekler pāresi bu Kāmilialsıñ İlāh

Cümle 'uşşāḳa tefāhur eylese olmaz mı yā 


\section{MUSAMMATLAR}

\section{MUHAMMES s.20-22}

fā'ilātün/ fā'ilātün/ fā'ilātün/ fā'ilün

1

Dilberi celb eylemekse niyyetiñ ' āşı̣ eger

Siḥr ü efsūn zaḥmetiyle zāatıña virme żarār

Bul anı kim yāri celb aġyārı hem tefrīk ider

Bir mü'esssir nüshadır kim nāmı anıñ sīm ü zer

Kanḳı maḥbūba virürseñ sīne bendin tīz çözer

2

Dil-rübāyı āgūşş-1 ag̉yārda gördüm seherer

[Ḥu]bb-1 nāza mübtelā serhôş̧-veş meh-veş batar

Sìm ü zer almış eline būse'i ḳandan șatar

Bir mü'esssir nüshadır ki nāmı anıñ sìm ü zer

Kanḳı maḥbūba virürseñ sīne bendin tīz çözer

3

La' lini șunmış rakīibiñ ag̉zına aldım ḩaber

Nāz u istignnā ile āhū gözün țurmaz süzer

Kīsesinden akç̧eniñ cevdetlisin bir bir seçer

Bir mü'esssir nüsḩadır ki nāmı anıñ sīm ü zer

Kanġı maḥbūba virürseñ sīne bendin tīz çözer 4

Tīr-i āhımdan ' aceb dil-ber niçün itmez ḩazer

Pīş-i ag̉yāre oturmuş ḳatlime fermān yazar

Bed-raḳibān ceybine çün șurre-i zerrīn atar

Bir mü' 'esssir nüshadır ki nāmı anıñ sìm ü zer

Kanḳı maḥbūba virürseñ sīne bendin tīz çözer

5

Eşk-i çeşmim țurmayup cūlar gibi dā 'im aḳar

Gül' izāārñ nār-1 hecri her nefes sīnem yaḳar

Pāresin ahzz eyleyüp illerle ol keyfin çatar

Bir mü'esssir nüsḩadır ki nāmı anıñ sīm ü zer

Kang̀ı maḥbūba virürseñ sīne bendin tīz çözer 
188 | A. ERDEMIR / Amasyalı Abdurrahman Kâmil (Yetkin) Efendi'nin Şairliği ve Türkçe Şiirleri

6

Rişte-i taḥrīe Kāmil sīm ü zerle dür düzer

(s.22) O cefā-pişse eger luṭf eyleyüp itse naz̧ar

Terk idüp aġyārı derḥāl sūyuma eyler güzer

Bir mü 'esssir nüsḩadır ki nāmı anıñ sīm ü zer

Kanġ1 maḥbūba virürseñ sīne bendin tīz çözer

2. MÜSEMMEN $^{34}$ s.87-88

fe'ilātün/fe'ilātün/fe'ilātün/ fe'ilün

1

Varayım ag̉layaraḳ pāyına yüzler süreyim

Buña bā'is ne imiş bāri dilimle șorayım

Var ise cürmüm eger dehrde ben ne turayım

Bu şirīn cānımıñ itlāfinı lāyık göreyim

Çekeyim tïgımı ben kendime kendim urayım

Cānı cānānıma bir peyk ile tīz göndereyim

2

Kendim 'azm itsem eger şimdi țaḳup boynuma tavk

Belki söyletmeden evvel ura bu sineme ok

Ey șabā sen biliñ ol yār ile var bunca hụụūḳ

Yüz süre pāyiñe var hālimi ' arż eyle çabuk

'Afv iderse șuçumı gerçi bugünden tezi yok

Yohsa bir merkez-i zulme idecekse o lühūḳ

Çekeyim tïgımı ben kendime kendim urayım

Cānı cānānıma bir peyk ile tīz göndereyim

3

Seyf-i ebrūyı çeküp ḩışmile ol hüsn-i melek

Cānımı ister imiş vay baña virmem ne dimek

Söylesün her ne ise söyle benim cürmümi tek

Kalmayım bāri tehayyürde emān mahşsere dek

Rāżıyım ben de ne çāre bu deyü hükm-i felek

(s.88) Cümle itdiklerimi dünyede buldum diyerek

Çekeyim tìgımı ben kendime kendim urayım

Cānı cānānıma bir peyk ile tīz göndereyim

34 87. sayfada başlayan bu müsemmenin ilk bendi iki mısra noksandır. Muhtemelen bu şiirin bulunduğu sayfa, metne sonradan yapıştırılarak eklenmiştir. 
4

Var șabā șor bu benim ḳatlime fermān ne imiş

Cānımı istemede maḳṣad-1 cānān ne imiş

Görelim kūy-1 ' adūda bize bühtān ne imiş

Virse de bir iki gün ḳatlime meydān ne imiş

Kendi isterse eger cānımı bir cān ne imiş

Eylemek cānımı cānānıma ḳurbān ne imiş

Çekeyim tìgımı ben kendime kendim urayım

Cānı cānānıma bir peyk ile tīz göndereyim

5

Halk olunmaḳda iken ins ü melek arż u semā

Gelmeden ketm-i 'ademden bu tenim 'āleme tā

Alnıma ḩāme-i ḳudretle yazılmış bu ḳażā

'Afvımı itme șabā nāfile ol yāre ricā

Belki ḥaḳkıımda budur çāre ne taḳdīr-i Hुudā

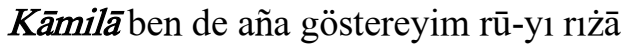

Çekeyim tïgımı ben kendime kendim urayım

Cānı cānānıma bir peyk ile tīz göndereyim

\section{GAZELLER}

\section{GAZEL s.6-7}

fă'ilātün/ făcilātün/ fācilātün/ făcilün

Dil yine bir şeh-levendiñ 'aşḳına sevdālıdır

Gözleri şehlā vü ruhsārı güli ḥamrālıdır

Yek-naẓarda ḩāṭr-1 nā-şādımı tārāc iden

Meh yüzinde hāle-veş ibnü'l-` arab ber-ḥālidir

Bū-yı rū-y1 āliniñ șorsañ baña fi 'ātını

Beyc olan biñ altuna ancaḳ anıñ mișḳālidir

Dişleri dürr-i cināndır zülfleri c anber-feşān

Cebhesi cāy-1 emāndır ḳaşları tuggrālıdır

Lebleri teng-i şekerdir ruhları reşk-i ḳamer

Mū miyānı zer-kemerdir luṭf anıñ ahvālidir 
190 । A. ERDEMIR / Amasyalı Abdurrahman Kâmil (Yetkin) Efendi'nin Şairliği ve Türkçe Şiirleri

(s.7) Dāyesinden sinniniñ çend oldig̀ın itdüm su'āl

Didi bu sāl o ġazāliñ on üçünci sālidir

Dā ġ-1 'aşḳıyla o cān-1 cān-fezānı̃̃ Kāmilā

$\mathrm{Bu}$ dil-i sūziş fa' ālim lāle-veș tamğalıdır

2. GAZEL s.10-12

făcilātün/ fā'ilātün/ fā'ilātün/ fàcilün

Bir metā` ${ }^{`}-1$ bì-bahādır ey göñül kālā-y1 ' aşk

Serde püskülli belādır ey gönüül sevdā-yı ' aşk

Şol ezel bezminde kim ìcād olundı 'aşḳ-1 pāk

(s.11) Cebheme imlā olındı ey gönüul țugrāà-yı ' aşk

Cām-1 'aşḳı nūş idince yoḳdı bende ihtitiā̄r

Pes baña dād-1 Hुudādır ey göñul șaḥbā-y1 'aşk

Eşk-i çeşmin dā 'imā ruhsārına icrā ider

Agglamaḳla mübtelādır ey gönüü rüsvā-y1 'aşk

Kalbi reng-ā-reng ider ḳavs-1 ḳuzaḥ-āsā hemān

Beyt-i dilde bir cilādır ey gönül ma' nā-yı ' aşk

Niçe 'āşıḳlar ḳırıpdır keşt īsin bu lüccede

Sāḥili taḥte's-serāādır ey göñül deryā-yı ' aşk

Geçmeden cisr-i mecāzı hāṣıll olmaz 'aşḳ-1 Haḳ

Böyle yazılsa be-cādır ey gönül fetvā-yı ' aşk

Hasret-i dil-dār ile itdim temāşā ' ālemi

Ravża-i bî-intihādır ey göñül șaḥrā-yı ' aşk

Sāḥa-i ḳaṣr-1 dil-ārāda hemān pervāz ider

Kāṣıd-ı bezm-i șafādır ey göñül ' anḳā-yı ' aşk

Zülf-i yāriñ tārını șad pāre itmekdir hüner

Telde biñ hịikmet-nümādır ey göñül monlā-yı ' aşk 
Fikr ile intāc-1 eş ār eylemek z̧anneyleme

Cism ü cānı heb fedādır ey gönül da' vā-yı ' aşḳ

(s.12) O perī-zādı müsahhhar ḳılmag̉a her dem çalış

Pek mü 'esssir bir dư ādır ey göñül esmā-yı ' aşk

Kanḳı bir Kāmil kulı görse hemān mecnūn ider

Böyle bir ḥūrī-liḳādır ey gönüül Leylā-yı ' aşk

\section{GAAZEL $s .61$}

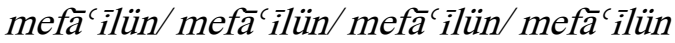

'Aceb var mı cihān içre benim tek bir cefã görmüş̧

Dil-ārādan vefā bekler iken her dem ezā görmüş

Nedendür bu felek devr eylemez aṣlā merām üzre

Ya yoḳsa hiç bulunmaz mı feleklerden șafā görmüş

Yolunda cān nișār itsem baña raḥm eylemez dil-ber

Cefāsın çekmeye her dem bu miskīni sezā görmüş

Dil-ārā zụlm ü cevrin 'āşık-1 nālānına eyler

'Ațā vü lüṭf u iḥsānın raḳīb-i bed-liḳā görmüş

Eyā Kāmil niçün șabr eylemezsin cevrine yāriñ

Kadīmdir ki bulunmaz hiç güzellerden vefā görmüş

\section{GAZEL s.65-66}

fằilātün/ făcilātün/ făcilātün/ făcilün

Of yārdan ayr1lı̣la itdigim feryāda of

Virdigim maḥsūl-i ‘ ömr-i nāzenīni bāda of

(s.66) Öyle of çekdim ki lerzān eyledi endāmımı

Āh n'ola bir iş göreydi meclis-i bālāda of

Dil-berin cevrin görüp ālüfte oldum ofla

Of baña itdi ta' alluk ben ofa sevdāda of 
192 | A. ERDEMIR / Amasyalı Abdurrahman Kâmil (Yetkin) Efendi'nin Şairliği ve Türkçe Şiirleri

Yāriñ ag̉yāre vișālin țuydıġımda ben ' aceb

Beyt-i ahzāna girüp itmez miyim tenhāda of

Āteş-i hicrānda yandı Kāmilā cism ü tenim

Āh vuṣlat eyleseydim yāre tek ma' nāda of

5. ĠAZEL s.66-68

$\mathrm{fe}$ 'ilātün/ fec ilātün/ fec ilātün/fec ilün

Bu ḳadar ḥasrete șabr idemezem sulțānım

Dīdeler yaş yerine aḳıdıyorlar ḳanım

'Acebā hāṭ̣̂r-1 ' ăṭ̂rda gezer mi nāmım

Yohssa peyġūle-i nisyāna mı atdıñ huānım

Hูăṭ̂r- 1 fătirimi șormamaḳ olmuş saña huy

Göziñe ḳılca görinmez bu ḳadar giryānım

(s.67) Dimediñ nār-1 firāḳıñla naṣı1dır ḥāliñ

Neye müncer olacaḳ gözleyelim nālānım

Leb-i la' liñ gibi çeşmim ḳızarır firḳat ile

Ġavṭa-zendir yemm-i hūn içre dilā müjgānım

Niçe ārām ideyim sensiz eyā şāh-1 hüsn

Sitem-i hüüzn ile āvīze gibi lerzānım

Dilimi cā-yı sürūr eyle dilā vuṣlat ile

Kuluñam ḩāk-1 peyim hāak-i dere yeksānım

Gelivir ḳandasın ey āfet-i devrān ḳanda

Güleyim vaṣlıñ ile bir daḩı ' āli-şānım

Ay kim dūr olalı sen şeh-i hūūānımdan

Șūretiñ ḩāne-i dilde şeb ü rūz mihmānım

İderem āh ile evḳātımı her dem imrār

Yine senden olacak derdime cān dermānım 
Bu güzellikde saña yoḳsa dil-ārā emșāl

Bulunur mı ya benim 'aşḳda hịç aḳrānım

Niçe bir hecriñ ile bu dil-i pür-ġam yanacak

Ay kim țaş degilim ben daḥı bir insānım

Çile-i ' aşḳ1 temām eyleyüp oldum Kāmil

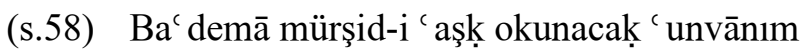

6. GAZEL ${ }^{35}$ s. 90

făcilātün/ făcilātün/ fă‘ilātün/ făcilün

Çeşm-i lüțfuñla kime itdiñse cānānım naẓar

Koymadıñ gerd-i küdūretden dilinde bir eserer

Bir girişmeñle dil-i maḥzūnuma virdiñ żiyā

Hīç siyāh olur mı āyā huāne țog̉duḳda ḳamer

Ben saña bir bendeyim ki ' itḳı hịç itmem ḳabūl

Hidmetiñde Kāmilem ammā ki gāayet mu' teber

\section{Kaynakça}

Arslan, Mehmet. "Mihrî Hâtun Divanı'nda Sanatlı Manzumeler". Uluslararası Amasya Âlimleri Sempozyumu Bildiriler Kitab1 2(21-23 Nisan 2017). Ed. Şuayip Özdemir - Ayşegül Gün. 2: 24-38. Ankara: KIBATEK, 2017.

Batman, Mustafa Murat. "Osmanlı'nın Son Döneminden Cumhuriyete Uzanan

Bir Âlim: Amasyalı Abdurrahman Kâmil (Yetkin) Efendi”. Uluslarası Amasya Âlimleri Sempozyumu Bildiriler Kitab1 2 (21-23 Nisan 2017). Ed. Şuayip Özdemir - Ayşegül Gün. 2: 509-515. Ankara: KIBATEK Matbaas1, 2017.

Hüseyin Hüsameddin. Amasya Tarihi. 1. Baskı. 4 Cilt. İstanbul: Hikmet Matbaas1, 1327.

Köksal, M. Fatih. Son Dönem Divan Şairlerinden Kütahyalı Vasfi Dîvânı. İstanbul: Kesit Yayınları, 2016.

35 Bu gazel, üç beyitten oluşması sebebiyle nakıs bir gazeldir. 
194 । A. ERDEMIR / Amasyalı Abdurrahman Kâmil (Yetkin) Efendi'nin Şairliği ve Türkçe Şiirleri

Kurt, Songül Keçeci. "Son Dönem Osmanlı Ulemasının Önemli Şahsiyetlerinden Abdurrahman Kāmil Efendi (1850-1941)". Türkiyat Araştırmaları DergisiJournal of Turkish Researches Institute 60 (2017): 477-494.

Mecdîzâde Abdurrahman Kâmil Efendi. Divançe. Yz. A 8993: 1-99. Milli Kütüphane Yazmalar Koleksiyonu.

Okuyucu, Cihan. Cinânî, Hayatı, Eserleri, Dîvanının Tenkidli Metni. Ankara: Türk Dil Kurumu Yayınları, 1994.

Özel, Recep Orhan. “Amasya'da Bir Âlim Yuvası: Mecdîzâde Abdurrahman Kâmil Yetkin (Ö.1941) ve Oğulları Mehmet Sabri Yetkin (Ö.1963), Ahmet Emrî Yetkin (Ö.1974), Mustafa Niyazi Yetkin (Ö.1959)". Amasya Üniversitesi Illahiyat Fakültesi Dergisi 6/10 (2018): 39-72.

Sarıkoyuncu, Ali. "Millî Mücadelede Amasya Müftüleri (Hacı Tevfik ve Abdurrahman Kâmil Efendiler)". Diyanet Ilmi Dergi 31/2 (1995): 61-100.

Şahin, Kâmil. “Abdurrahman Kâmil Yetkin”. Türkiye Diyanet Vakfi Íslam Ansiklopedisi. 43: 504-505. Ankara: TDV Yayınları, 2013. 